\title{
International relations and domestic structures: Foreign economic policies of advanced industrial states
}

\author{
Peter J. Katzenstein
}

\begin{abstract}
Recent writings on problems of the international economy have focused attention primarily on changes in the international system. This paper attempts to show that foreign economic policy can be understood only if domestic factors are systematically included in the analysis. The paper's first part groups the recent literature into three paradigms which distinguish between three international effects. The second part offers a comparison of the differences between a state-centered policy network in France and a society-centered network in the United States. The third part of the paper combines the arguments of the first two and analyzes French and American commercial, financial, and energy policies as the outcome of both international effects and domestic structures. These case studies show that domestic factors must be included in an analysis of foreign economic policies. The paper's main results are analyzed further in its fourth part.
\end{abstract}

In recent years students of international politics have devoted an increasing amount of attention to the growing impact of international effects on the foreign economic policies of advanced industrial states. ${ }^{1}$ The central conclusion of this paper is in

Peter J. Katzenstein is a member of the Department of Government at Cornell University. For their helpful comments on earlier drafts of this paper I would like to thank Peter Gourevitch, Gerhard Katzenstein, Robert O. Keohane, Stephen D. Krasner, David Laitin, Theodore J. Lowi, Joseph S. Nye, Richard N. Rosecrance, Robert W. Russell and Lawrence Scheinman. I have also learned much from a discussion of this paper by the Harvard Faculty Seminar on "State and Capitalism since 1800" and by the Junior Faculty Research Seminar of the Cornell Government Department.

${ }^{1}$ This analysis is intended to apply primarily to the OECD members. Although all of these states are capitalist, I have deliberately used the term 'advanced industrial states.' The owner- 
partial contradiction to that line of research, and it questions policies based solely on such a premise. The consistency and the content of foreign economic policies result at least as much from the constraints of domestic structures as from the functional logic inherent in international effects. If supported and suitably refined through further analysis, this conclusion may bear on the analysis of contemporary international politics. Since it accords a central position to factors somewhat neglected in recent writings on international relations and foreign economic policies, some modification and extension of existing interpretations may be necessary. Such a reorientation would have the undeniable virtue of making political analysis in this field again compatible with common sense. It has struck me as odd that the recent shift from military to economic issues in international politics was not accompanied by a corresponding shift from foreign to domestic political analysis. Plausibility speaks for adopting a type of analysis which differs depending on whether it deals with the sandbox of the strategist or the pocketbook of the entrepreneur. Since the primary constraints on government policy have shifted away from the international and toward the domestic level, foreign and domestic affairs have become closely intertwined. Analysis of contemporary foreign economic policies is inadequate as long as it focuses only on the "internalization" of international relations; the "externalization" of domestic structures is also of great importance.

The recent literature can be grouped into three paradigms which distinguish between three distinct international effects. The first effect is interpenetration; it has been systematized into the nationalist paradigm which focuses on the volume of transactions exchanged between societies and the predictability of behavior. The second effect is interdependence; it has been analyzed by the realist paradigm which draws attention to the costs of interstate relations and the vulnerability of governments. The third effect is interconnection; and it has been noted by the neo-liberal paradigm which emphasizes the diffusion of social and economic practices and the sensitivity of economics to developments between and within societies and states. In this paper I propose to analyze some aspects of foreign economic policies in terms of these three international effects. Widely, if implicitly, adhered to in the literature, this type of analysis postulates that the functional characteristics of the different international effects will lead to roughly similar but not

\footnotetext{
ship of the means of production, I concluded, was less important for explaining foreign economic policy than the nature of the policy networks linking the public with the private sector. A French quip sums this up well: "French business is divided into a private sector, rigidly controlled, and a public sector, completely free." Quoted in M. A. Adelman, The World Petroleum Market (Baltimore: Johns Hopkins University Press, 1972), p. 236. See also Raymond Vernon, The Economic and Political Consequences of Multinational Enterprise: An Anthology (Boston: Division of Research, Graduate School of Business Administration, Harvard University, 1972), p. 117. Bruce Andrews has recently offered a line of argument about the importance of domestic politics for foreign policy analysis which complements this paper. See his "Social Rules and the State as a Social Actor," World Politics, 27, 4 (July 1975): $521-40$.
} 
necessarily harmonious policy responses of advanced industrial states. These analytical distinctions are developed at greater length in the first part of this paper.

Instead of focusing on international effects, an alternative approach, proposed in the paper's second part, analyzes types of domestic structures which also shape government policy. The growing importance of domestic politics has been noted by several authors. Keohane and Nye, for example, have argued that in the new era of international relations "the general question [of peace and war] bears enough relationship to critical questions of comparative politics as well as to traditional concerns of students of international politics that both sets of literature should be relevant ... As interdependence blurs the distinction between domestic and international politics in some settings, the two fields become more relevant to each other."2 And in his recent reflections on current international problems Henry Kissinger noted that "almost every nation right now has the problem of reconciling its domestic view of itself with the international problem because every nation has to live on so many levels." 3 Unfortunately these suggestions have not been followed. In his provocative writings on transnationalism, for example, Edward Morse has made only perfunctory references to domestic politics. ${ }^{4}$

The reason for this lack of attention to domestic politics lies, I think, in the presumed similarity and homogeneity of advanced industrial states. Nye and Keohane, for example, argue that "among the major non-socialist trading and investing nations, there is a remarkable degree of political similarity, at least at a very general level: All of them have competitive, as opposed to authoritarian or mass mobilization, political systems." 5 And Richard Cooper writes, "there is a second, and for our purposes more powerful, reason for directing attention to the Atlantic countries. There has been a marked convergence in the economic systems and economic objectives of these countries. Despite occasional ideological claims to the contrary, they all involve a refined mixture of free enterprise and government activity. The mixture varies from country to country, but the narrowness of variation stands in marked contrast to the polarized laissez-faire and corporate state systems of the interwar period." One man's molehill is another man's mountain. Differences which to the specialist in international politics and economics appear minor are the

\footnotetext{
${ }^{2}$ Robert O. Keohane and Joseph S. Nye, "International Interdependence and Integration," unpublished paper, 1973, p. 77. A revised version of this paper appears in Fred I. Greenstein and Nelson W. Polsby (eds.), Handbook of Political Science (Reading, Mass., Addison-Wesley), volume 8, International Politics, ch. 5. Page references here are to the earlier manuscript version.

${ }^{3}$ New York Times, October 13, 1974, p. 34.

${ }^{4}$ Edward L. Morse, "The Politics of Interdependence," International Organization, 23, 2 (Spring 1969): 311-26. Morse, "Crisis Diplomacy, Interdependence and the Politics of International Economic Relations," in Raymond Tanter and Richard H. Ullman (eds.), Theory and Policy in International Relations (Princeton, N.J.: Princeton University Press, 1972), pp. 123-50. Morse, Foreign Policy and Interdependence in Gaullist France (Princeton, N.J.: Princeton University Press, 1973).

${ }^{5}$ Keohane and Nye, "Interdependence and Integration."

${ }^{6}$ Richard N. Cooper, The Economics of Interdependence: Economic Policy in the American Community (New York: McGraw-Hill, 1968), pp. 7-8.
} 
stuff which provides students of comparative political and economic systems with a living. Government policies can be explained in terms of the nature of domestic policy networks which link state and society. Neglected, perhaps unduly, in the recent international relations literature, this domestic explanation postulates that differences in the constraints of domestic structures will result in dissimilar policy responses of advanced industrial states. Although it is intended for possibly broader application, the second part of this paper considers in greater detail only two states, France and the United States.

The third part combines the arguments of the first two and applies the international and domestic explanation to a comparative analysis of French and American commercial, financial, and energy policy. The evidence presented there shows that a domestic explanation is indispensable for an analysis of foreign economic policy. Finally, the paper's main results are analyzed in its fourth part.

\section{Types of international effects}

Much of the recent literature on international relations draws together elements of three alternative paradigms. These paradigms are derived from nationalist, realist, and neo-liberal theories of international politics. ${ }^{7}$ The nationalist paradigm is concerned with questions of identity. Its underlying assumption is the primacy of domestic politics, and it focuses primarily on an analysis of society. The realist paradigm has an interest in questions of security. Its basic assumption is the primacy of foreign policy, and it concentrates primarily on an analysis of the state. The neo-liberal paradigm deals with questions of prosperity. It assumes as well as argues the case for the intermingling of domestic and foreign policy and of society and state.

\section{Nationalist paradigm}

The core concept of the nationalist paradigm is identity which is affected by the interpenetration of different societies. This interpenetration is defined in terms of the predictability of mutual behavior within societies and is measured by the volume of goods, services, and people exchanged between them. In the past the paradigm has been applied primarily to problems of national and supranational integration.

Karl Deutsch has analyzed the volume of transaction flows in the international system more persistently than anyone else. ${ }^{8}$ With the European Left Deutsch

\footnotetext{
${ }^{7}$ The realist and neo-liberal paradigms are also treated in Robert Gilpin, "Three Models of the Future," International Organization 29, 1 (Winter 1975): 37-60; Gilpin, American Hegemony and the Multinationals: The Political Economy of Foreign Investment (New York: Basic Books, 1975); see also Stephen D. Krasner, "State Power and International Economic Structure," unpublished paper.

${ }^{8}$ Karl W. Deutsch, "Communication Theory and Political Integration," in Philip E. Jacob and James V. Toscano (eds), The Integration of Political Communities (Philadelphia: J.B. Lippin-
} 
shares a perspective on international relations which stresses the primacy of domestic factors in the shaping of international politics. In the course of modernization, he concluded, flows within societies have grown faster than flows between societies. Cosmopolitanism of the few at the top of society and parochialism of the many at its bottom have fused into an overarching nationalism. ${ }^{9}$ But at the same time the process of modernization was marked also by a diffusion of formal political power from the top of society downward. These two trends led Deutsch to the conclusion that national rather than international processes would increasingly shape government policies in the twentieth century.

Deutsch conducted two major empirical studies designed to trace some of these changes, and both studies pointed to the same conclusion, a long-term decline in the ratio of foreign to domestic flows. ${ }^{10}$ He charted changes in trade and mail flow data for many countries since the late nineteenth century. These data were readily available for analysis and, he argued, were linked to the political process. Deutsch assumed that changes in the foreign trade sector reflect a power process, and changes in the foreign mail sector a communication process. And so, for Deutsch, politics could best be understood as a combination of power and communication processes. ${ }^{11}$ The relative share of the foreign trade sector represents for Deutsch the potential power base for political organizations, economic classes, and social or cultural status groups which are directly involved in and tangibly affected by changes in international relations. ${ }^{12}$ Deutsch then concludes that the systematic erosion in the potential power base of these organizations, classes and groups in most societies has a direct effect on the organization of

cott, 1964), pp. 46-74. Karl W. Deutsch, The Analysis of International Relations (Englewood Cliffs, New Jersey: Prentice-Hall, 1968). Karl W. Deutsch, Political Community at the Supranational Level: Problems of Definition and Measurement (Garden City: Doubleday, 1954). Karl W. Deutsch, Lewis J. Edinger, Roy C. Macridis, and Richard L. Merritt, France, Germany and the Western Alliance: A Study of Elite Attitudes on European Integration and World Politics (New York: Charles Scribner's, 1967), pp. 218-39. Richard W. Chadwick and Kar1 W. Deutsch, "International Trade and Economic Integration: Further Developments in Trade Matrix Analysis," Comparative Political Studies, 6, 1 (April 1973): 84-109.

${ }^{9}$ Karl W. Deutsch, Nationalism and Social Communication: An Inquiry into the Foundations of Nationality, 2nd ed., (Cambridge, Mass.: MIT Press, 1966). Karl W. Deutsch, Nationalism and its Alternatives (New York: Alfred A. Knopf, 1969). Karl W. Deutsch, "The Growth of Nations: Some Recurrent Patterns of Political and Social Integration," World Politics, 5, 2 (January 1953): 168-95. Karl W. Deutsch, "Nation and World," in Ithiel de Sola Pool (ed.), Contemporary Political Science: Toward Empirical Theory (New York: McGraw-Hill, 1967), pp. 206-27. Karl W. Deutsch, "Social Mobilization and Political Development," American Political Science Review 55, 3 (September 1961): 501.

${ }^{10} \mathrm{Karl}$ W. Deutsch and Alexander Eckstein, "National Industrialization and the Declining Share of the International Economic Sector, 1890-1959," World Politics 13, 2 (January 1961): 267-99. Karl W. Deutsch, "International Communications: The Media and Flows," Public Opinion Quarterly 20, 1 (Spring 1956), 143-60. The conclusions of these two studies reappear in different forms in many of Deutsch's subsequent writings on problems of international interdependence.

${ }^{11}$ Karl W. Deutsch, The Nerves of Government: Models of Political Communication and Control (New York: The Free Press, 1966).

${ }^{12}$ Deutsch and Eckstein, "National Industrialization," p. 271. 
domestic political power and the purposes to which that power is applied. Changes in the foreign mail sector, on the other hand, he argued, are communication processes which indicate changes in the decision-making process of governments. The decline of the foreign sector which Deutsch discovered points to the enormous increase in the volume of domestically generated messages during the modernization process. Since governments have limited attention spans, an increase in their national preoccupation is highly probable. For Deutsch, the decline in the power of the foreign trade sector and the decline in the relevance of communications from other societies make highly probable a nationalist policy in response to the growth of international relations.

One of the central analytical problems of the nationalist paradigm is the gap between the theoretical definition of interpenetration as the predictability of mutual behavior on the one hand and the way in which that interpenetration is measured empirically. The choice of foreign trade as an indicator of a power process and foreign mail as an indicator of a communication process makes sense at best only as a first approximation. More detailed linkages to the political process are required, yet these links have never been specified in the nationalism literature which first developed the concept of interpenetration and subsequently measured the volume of transaction flows in the international system. The choice of the foreign trade sector as an indicator of the potential power base of politically organized socio-economic groups points to an Anglo-Saxon view of politics as a pluralistic bargaining process. ${ }^{13}$ Yet a growing body of data has revealed important theoretical and empirical deficiencies of the pluralist model. After it has specified the economic resource base of different groups, the nationalist paradigm simply assumes rather than analyzes the political process.

Deutsch's analysis also draws an inference from mail flow data to communications flows in society and in the state. This procedure is highly speculative because it occurs in two steps: First from mail to social communications, then from social to political communications. Only the first of these two steps is plausible. As an extension of cybernetic models of politics, the nationalism paradigm is certainly right in pinpointing the critical importance of government attention patterns and of the information stream which reaches the bureaucracy. It is possibly also correct in amending Weber's view of bureaucracy as rational organization. Its theoretical description points out how information is selectively filtered through multiple layers of standard operating and blocking procedures of bureaucratic organizations as it is channeled upward in the bureaucratic hierarchy. ${ }^{14}$ But this

\footnotetext{
${ }^{13}$ Karl W. Deutsch and Lewis J. Edinger, Germany Rejoins the Powers (Stanford: Stanford University Press, 1959).

${ }^{14}$ Deutsch, Nerves of Government, Part III. Karl W. Deutsch and J. David Singer, "Multipolar Power Systems and International Stability," World Politics, 16, 3 (April 1964): 390-406. See also the growing literature on bureaucratic politics and foreign policy behavior first systematized by Graham T. Allison, Essence of Decision: Explaining the Cuban Missile Crisis (Boston: Little, Brown and Co., 1971).
} 
process is not adequately measured by indicators of social communications. An important weakness in the political inference which this type of analysis draws from power and communication processes in society is a view of politics as lacking its own dynamic of power and influence.

The nationalist paradigm, nonetheless, contributes two important insights to an analysis of the policy responses to international relations. The mutual interpenetration of societies as, for example, through trade, is undoubtedly one important empirical aspect of recent developments. That interpenetration will impinge on the economic needs and cultural aspirations of members of society and thus shape policy. Furthermore, the analysis of the availability of relevant information and adequate communications capacities of increasingly fragmented government bureaucracies is an important theoretical insight into problems of policy making. It points to the political importance of the process by which government bureaucracies formulate and implement their policy responses to changes in international relations; with growing bureaucratization those responses are likely to become less effective.

\section{Realist paradigm}

Security, affected by the interdependence of states, is the central concept of the realist paradigm. Interdependence is defined in terms of the vulnerability of governments. It can be measured by the asymmetry of costs involved in breaking a set of relationships. The realist paradigm has traditionally been applied to problems of national security. ${ }^{15}$

This paradigm has a long intellectual tradition which incorporates elements from eighteenth century mercantilist theory, nineteenth century balance of power theory, and twentieth century strategic theory. The realist paradigm shares with the European Right a perspective on international politics which stresses the primacy of foreign policy. Its image of international politics is not one of social communications between societies but of diplomatic bargaining between states. The calculation of benefits and costs in that process of bargaining has remained relatively unaffected by the process of modernization. Whether harnessed to the purpose of security or prosperity, state power prevails in politics. In the international arena the game of politics can be played on one or several chess boards but today the security and prosperity game share the center table. ${ }^{16}$ Although a small number of illustra-

\footnotetext{
${ }^{15}$ See the references cited in footnote 7 above and David P. Calleo and Benjamin M. Rowland, America and the World Political Economy: Atlantic Dreams and National Realities (Bloomington, Ind.: Indiana University Press, 1973). Kenneth N. Waltz, "The Myth of National Interdependence," in Charles P. Kindleberger (ed.), The International Corporation (Cambridge, Mass.: MIT Press, 1970), pp. 205-23. Richard N. Rosecrance and Arthur Stein, "Interdependence: Myth or Reality?" World Politics 26, 1 (October 1973): 1-27.

${ }^{16}$ Robert Gilpin, "The Politics of Transnational Economic Relations," in Robert O. Keohane and Joseph S. Nye, Jr. (eds.). Transnational Relations and World Politics (Cambridge, Mass.: Harvard University Press, 1972), pp. 48-69.
} 
tive case studies have been written from this perspective, there is still a great dearth of detailed empirical analysis. ${ }^{17}$ This gap in the current literature is deplorable for the simple reason that opportunity costs on economic issues are more commensurable than on security issues. In a balance of payments crisis the economic costs and benefits of alternative strategies of devaluation or deflation can be calculated more accurately than can security costs and benefits of alternative strategies of deterrence or defense in a balance of power crisis. ${ }^{18}$

Like the rational actor model which has informed strategic analysis and the economic theory of perfect competition, the realist paradigm focuses on government action as goal-oriented, rational choice behavior. Like generals or entrepreneurs, political decision makers are thought of as endowed with maximum information, as carefully calculating the trade-offs between different strategies, and intent on maximizing political benefits in their strategies and bargains. In recent years Calleo and Rowland and Robert Gilpin have come closest so far to providing analyses of international relations from a perspective of political realism. ${ }^{19}$ In contrast to the national and neo-liberal alternatives, the realist paradigm focuses on the state as a unitary actor undivided by class conflict, social tension, cultural fragmentation and, most importantly, bureaucratic rivalries and stalemate. The realist paradigm analyzes the state, not society. It views the role of the state in the era of rockets and the balance of terror as unchanged from the age of railways and the balance of power. Governments are unencumbered by the societies they rule and the bureaucracies they control. They are cohesive collectivities in pursuit of rational political strategies. Like nineteenth century balance of power theory, the realist paradigm views the state as capable of effective governance. Economic conditions do not create political choices. Instead, political choices create economic conditions. The argument, in short, is one for the primacy of the state in domestic and foreign policy.

A key problem of the realist paradigm is its insistence on explaining government policy exclusively in terms of the pattern of asymmetric dependencies which define the politically most volatile and interesting features of the international state system. These dependencies are said to create differences in mutual vulnerability which shape government policies so that no other factors have to be considered.

\footnotetext{
${ }^{7}$ But see Albert O. Hirschman, National Power and the Structure of Foreign Trade (Berkeley: University of California Press, 1945). Stephen D. Cohen, International Monetary Reform, 1964-1969: The Political Dimension (New York: Praeger Publishers, 1970). Gilpin, American Hegemony and the Multinationals. Robert W. Russell, "Crisis Management in the International Monetary System, 1960-1973." Paper prepared for Delivery at the International Studies Association Convention, New York City, March 16, 1973. B. Haskel, "Disparities, Strategies, and Opportunity Costs: The Example of Scandinavian Economic Market Negotiations," International Studies Quarterly, 28, 1 (March 1974): 3-30.

${ }^{18}$ For one such attempt applying event interaction analysis see Brian Healey, "Economic Power Transition in the International System: The Translation of Economic Power into Political Leverage in the International Monetary System," (Ph.D. Dissertation, Cornell University, 1973).

${ }^{19}$ Calleo and Rowland, America and the World Political Economy.
} 
This may well have been an adequate starting point for analysis in the 1950 s and 1960 s when security concerns were overriding in world politics. Then, relatively small foreign policy machineries defined and implemented policies primarily in response to changes in vulnerability in the continuing global confrontation of the two superpowers. With the shift toward economic issues in recent years and with the growth in the size and number of government agencies involved in foreign operations, key features of contemporary international politics have changed in defiance of the rationalist logic of the realist paradigm.

Yet, the realist paradigm also has two important insights for an analysis of the international effects on government policy. Changes in the vulnerability of states are always relative, not absolute. In response to an increasing importance of international relations, government policy is therefore likely to remain geared more to considerations of power than of prosperity. Furthermore, governments can fashion effective policies if problems of administrative red-tape and duplication can be solved either by cultural adaptation or by conscious design.

\section{Neo-liberal paradigm}

The key concept of the neo-liberal paradigm is prosperity and in recent years this prosperity has become increasingly affected by the interconnection of different societies and states. ${ }^{20}$ Interconnection is defined in terms of the mutual sensitivity of behavior within societies. It can be measured, for example, by the elasticities of demands and supplies across state boundaries, by the factor-price equalization of units of production, by the diffusion of social innovations across borders or by the contingency of behavior broadly defined. The neo-liberal paradigm is an adaptation of neo-classical international trade theory to problems of international relations.

The neo-liberal paradigm has been developed by writers such as Cooper and Morse to illustrate how with the growth of sensitivity the interconnections of societies and states have increased. Even marginal changes in international relations can lead to large policy responses in domestic and foreign affairs. New issues and new actors (nongovernmental and sub-governmental), it has been argued, lead to more intimate relations between domestic and foreign policy and between society and state. This requires a fundamental reorientation in the study of international politics. The realist paradigm had focused first in the 1950s on the loss of the nation-state's "impermeability" above the threshold of nuclear war, later in the

\footnotetext{
${ }^{20}$ A recent statement can be found in Cooper, The Economics of Interdependence. This book has been central to the reformulation of international relations theory attempted by Keohane and Nye, in Transnational Relations and World Politics, pp. 371-98. In addition to Morse's articles quoted in footnote 4 above see also his paper, "Interdependence in World Affairs," unpublished paper. Ernst B. Haas, "Is there a Hole in the Whole? Knowledge, Technology, Interdependence and the Construction of International Regimes," International Organization 29, 3 (Summer 1975). Oran R. Young, "Interdependencies in World Politics," International Journal 24, 1 (Winter 1968-1969): 726-50. Werner J. Feld, Nongovernmental Forces and World Politics: A Study of Business, Labor and Political Groups (New York: Praeger Publishers, 1972). Lester R. Brown, World Without Borders (New York: Random House, 1972).
} 
1960 s on its "informal penetration" below the threshold of conventional war. ${ }^{21}$ In a similar vein the neo-liberal paradigm views social and political sensitivities as permeating and penetrating the traditional nation-state. In the 1950s and 1960s the realist paradigm pointed to increasing political constraints on unilateral action and decreasing control over international events as twin outcomes of changes in strategic interdependence. The neo-liberal paradigm has arrived at the same conclusion for the 1970s and 1980s. This is both plausible and paradoxical. Although informed by economic theory this economic analysis suggests that increasing abundance breeds not choice but confinement. But in contrast to its realist alternative, the neo-liberal paradigm postulates that social and economic conditions have a large impact on government policies.

For the neo-liberal paradigm the technological revolution in transportation and communication is the primary agent of change which enhances the mutual sensitivity of societies and states. Political behavior may be mutually contingent not only despite, but because of, the absence of the transactions flows which are central to the nationalist paradigm. ${ }^{22}$ With increasing sensitivity governments can move to block further advances of international contacts. The change in American immigration legislation in the early 1920 s and the intervention of several European governments in international capital markets in the late 1960s are obvious examples. By and large, though, the scale of social and economic processes in the international system has increased. That increase is illustrated by changes in international capital markets which have grown rapidly over the last two decades. In one of the first serious currency crises of the Bretton Woods system, for example, 300 million dollars were converted into Swiss francs in a four-day period in March 1961. In one of the most recent currency crises in February-March 1973, 3 billion dollars were converted into European currencies at the height of the crisis in a single day. ${ }^{23}$ This change by an order of magnitude illustrates the growing importance of this international effect.

For political analysis the increase in social and political sensitivity is less interesting than the fact that governments feel compelled to manage domestically the effects of international interconnections. The scope of government policy, it is argued, has increased dramatically during the last two generations as have the expectations of citizens about the range of activity over which the government should exercise control and the political demands which organized groups now make on governments. The domestic implications of increases in interconnections between societies since 1945 are, therefore, not easily comparable to corresponding developments before World War I. Even in areas where interconnections have been

\footnotetext{
${ }^{21}$ John H. Herz, International Politics in the Atomic Age (New York: Columbia University Press, 1959). Andrew M. Scott, The Revolution in Statecraft: Informal Penetration (New York: Random House, 1965).

${ }^{22}$ Edward L. Morse, "Transnational Economic Processes," in Keohane and Nye, Transnational Relations, p. 40.

${ }^{23}$ Russell, “Crisis Management," pp. 3b, 35.
} 
constant or declining, over the last two generations the increase in the scope of government activity in domestic affairs has led to a potential politicization of existing interconnections which was simply lacking in the latter part of the nineteenth century. The "vertical" politicization of domestic affairs within states thus partially accounts for the "horizontal" politicization of the interconnections between societies. ${ }^{24}$

Strength and weakness in the neo-liberal paradigm are closely intertwined. Using concepts drawn from economic analysis, the neo-liberal paradigm views both foreign and domestic policy and society and state in an increasingly close interaction. That interaction has led to a decline in the number of policy instruments over which national governments can exercise autonomous control. At the same time, though, the number of political objectives has continued to increase. ${ }^{25}$ In the absence of further elaboration, this axiom of economic science has remained an inadequate analysis of both domestic and foreign policy. The reason for that inadequacy lies in the paradigm's studied ambiguity on a key point. Are the foreign and domestic factors and the societal and state forces categories-descriptive of a political world where social and political processes become increasingly interconnected or are they tools for explanation? With growing interconnections the list of factors which can plausibly be adduced to shape government policy grows rapidly. The hope for a parsimonious analysis vanishes and the distinction between description and explanation blurs.

These weaknesses notwithstanding, the neo-liberal paradigm suggests two critical insights into an analysis of international effects on government policy. Since it derives from economic analysis, the neo-liberal paradigm has been very successful over the last decade in picking up the shift from security to prosperity concerns in government policies as well as in pointing to the prominence of domestic factors in the expanding scope of policy. In addition it has drawn attention to the crosscurrents affecting government policy. On the one hand international forces of growing importance subject governments to the impartial and rigorous logic of the international market. On the other hand, these international forces also increase citizens' aspirations and demands and, with them, government objectives in domestic policies. A growing gap between objectives and the availability of effective instruments impairs government policy.

The nationalist, realist and neo-liberal paradigms specify three different international effects. In summary fashion table I presents the major features of each of the three paradigms. Table I illustrates that the three paradigms differ in their

\footnotetext{
${ }^{24}$ Edward L. Morse, "The Transformation of Foreign Policies: Modernization, Interdependence and Externalization," World Politics, 22, 3 (April 1970), pp. 371-92. See also Keohane and Nye, "Interdependence and Integration," pp. 19-20. Richard N. Rosecrance, "Contemporary Interdependence: An Introduction," in Richard N. Rosecrance and Arthur Stein (eds.), Interdependence in World Politics (forthcoming).

${ }^{25}$ Cooper, The Economics of Interdependence, p. 153. Morse, Foreign Policy and Interdependence, pp. 40-1.
} 
Table I: Three paradigms of international relations

\begin{tabular}{|c|c|c|c|}
\hline & $\begin{array}{l}\text { Nationalist } \\
\text { paradigm }\end{array}$ & $\begin{array}{c}\text { Realist } \\
\text { paradigm }\end{array}$ & $\begin{array}{l}\text { Neo-liberal } \\
\text { paradigm }\end{array}$ \\
\hline $\begin{array}{l}\text { Previous } \\
\text { application }\end{array}$ & $\begin{array}{l}\text { National and } \\
\text { supranational } \\
\text { in tegration }\end{array}$ & $\begin{array}{l}\text { Mercantilism, } \\
\text { Balance of power, } \\
\text { Strategy }\end{array}$ & $\begin{array}{l}\text { Neo-classical } \\
\text { Economics, Inter- } \\
\text { national trade }\end{array}$ \\
\hline Core concept & Identity & Security & Prosperity \\
\hline Level of analysis & International & International & $\begin{array}{l}\text { International and } \\
\text { domestic }\end{array}$ \\
\hline Unit of analysis & Society & State & Society and state \\
\hline $\begin{array}{l}\text { International } \\
\text { effect }\end{array}$ & Interpenetration & Interdependence & Interconnection \\
\hline -focusing on & Predictability & Vulnerability & Sensitivity \\
\hline -measured by & $\begin{array}{l}\text { Volume of } \\
\text { transactions }\end{array}$ & $\begin{array}{l}\text { Costs of } \\
\text { relations }\end{array}$ & $\begin{array}{l}\text { Diffusion of } \\
\text { behavior }\end{array}$ \\
\hline Political focus & $\begin{array}{l}\text { Primacy of } \\
\text { domestic policy }\end{array}$ & $\begin{array}{l}\text { Primacy of } \\
\text { foreign policy }\end{array}$ & $\begin{array}{l}\text { Interrelation of } \\
\text { domestic and foreign } \\
\text { policy }\end{array}$ \\
\hline
\end{tabular}

unit of analysis. The realist paradigm focuses on the interdependence of states and government behavior. The nationalist paradigm concentrates on the interpenetration of societies and group behavior. The neo-liberal paradigm focuses attention on intermediate levels of interaction between state and society. Different international effects thus operate at different levels in the policy networks which link state and society. In the interest of clarity of exposition these analytical distinctions may have been overdrawn in the preceding discussion. What unites the nationalist, realist and neo-liberal paradigms across many substantive differences is the assumption that the functional characteristics inherent in different international effects will act in a similar manner on the foreign economic policies of advanced industrial states.

Since they do not determine reality but merely help in ordering data about reality, these three paradigms should not be taken as unalterably given. In their writings Nye and Keohane have treated the three paradigms as complementary though distinct. Their work on international relations has sought to synthesize empirical findings and theoretical propositions which previously were developed and tested in mutual isolation. The "transnational paradigm" which they have elaborated can be interpreted as a first attempt to construct an eclectic, multicausal explanation of government policy which draws on different aspects of the 
nationalist, realist and neo-liberal paradigms. ${ }^{26}$ In trying to incorporate domestic factors into the analysis, this paper offers an alternative, eclectic explanation.

But the three paradigms summarized in table $I$ are not merely analytical tools devised for the interpretation of data. These paradigms are themselves factors which act and depend upon government policy. At any one time policy makers will subscribe to a mixture of these three paradigms. What is a core concept for political analysts-identity, security, prosperity-is a key value for political actors. These values are not mutually exclusive and an unending process of definition and reinterpretation informs the actions of political leaders. In turn, though, these political actions will affect value orientations and the analytical power of the three paradigms. A theory of international relations which is self-reflective-"critical" in the sense of the Frankfurt School-cannot afford to neglect the interrelation between paradigm and policy. Each of the three paradigms or their eclectic combination should be viewed not simply as a constant but as a variable which is closely interrelated with government policy.

\section{Types of domestic structures}

Government policy is also shaped by domestic structures. But none of the three paradigms focuses in a systematic fashion on an analysis of domestic factors. The nationalist paradigm merely assumes that the relative size of the sectors of society penetrated from abroad will be reflected in government policies, and that these policies will show the marks of bureaucratic fragmentation. The realist paradigm assumes that governments respond to changes in vulnerability relatively unencumbered by societal pressures, and that they have no serious problem in controlling their bureaucracies. Finally, the neo-liberal paradigm postulates, without offering additional analysis or evidence, a growing gap in domestic policies between the increasing number of economic objectives and the decreasing number of policy instruments. Domestic politics is very much treated as a residual category in current writings on international relations.

The neglect of considerations of domestic structure is illustrated by two recent publications. A special issue of International Organization on US-Canadian relations and Morse's book Foreign Policy and Interdependence in Gaullist France make their arguments for the pervasiveness and strength of international relations. North America and France are self-consciously chosen, limiting, cases. US-Canadian relations, Nye and Keohane argue, provide a weak test for a transnational explana-

${ }^{26}$ Keohane and Nye, Transnational Relations and World Politics, pp. ix-xxix, 371-98. See also Robert $\mathrm{O}$. Keohane and Joseph S. Nye, "World Politics and the International Economic System," in Fred C. Bergsten (ed.), The Future of the International Economic Order: An Agenda for Research (Lexington, Mass., D.C. Heath: 1973), pp. 115-79. J.S. Nye, "Oceans Rule Making in a World Politics Perspective," unpublished paper. Robert O. Keohane and Joseph S. Nye, "Transgovernmental Relations and International Organization," World Politics, 27, 1 (October 1974): 39-62. Joseph S. Nye, "Transnational Relations and Interstate Conflicts: An Empirical Analysis," International Organization, 28, 4 (Autumn 1974): 961-96. 
tion of policy responses. ${ }^{27}$ Compared to most other parts of the world transnational relations are blooming in North America. If the impact of these relations on policy is small here, it will be small everywhere. Conversely, Morse argues that France offers a strong test for the international explanation. ${ }^{28}$ More inclined than any other advanced industrial state to defend national sovereignty and political autonomy, throughout the 1960s France tried to minimize the impact of international relations on what was perceived to be French national interest. If international effects on policy are large in France, they will be large everywhere. Since the two books find abundant evidence of international effects, broadly defined, on government policy in both North America and France, the international explanation seems to have clinched its case.

This conclusion can, however, be disputed-for there exists an alternative domestic explanation of policy responses which is not easily integrated into the international framework and which leads to very different predictions. Diverging in matters of evaluation, Samuel Huntington and Marxist critics concur in their descriptions of the American Empire since 1945 as based on policies embodying not the principle of acquisition but the principle of access; not territory but function; not rule but presence. ${ }^{29}$. The informal American Empire downgraded state-centered responses to international relations because that Empire reflected the domestic conditions of the United States as a country marked by a strong society and a weak state. ${ }^{30}$ This being the case, it may seem paradoxical that, in contrast to the United States, French policy has by and large consisted of state-centered responses across the entire range of international relations. An analysis of French domestic structure resolves that paradox, for France is a country marked by a weak society and a strong state. The different forms of expansion of the American and French Empires can be seen as the projection of a society-centered and a statecentered policy network onto the stage of international politics. The French instrument for conquest was the military, the American was property. The French style of intervention was absorption, the American was exploitation. Finally, the French approached interstate relations in terms of treaties, the Americans in terms of contracts. The domestic explanation thus predicts a great dissimilarity

${ }^{27}$ Robert O. Keohane and Joseph S. Nye, Jr., "Introduction: The Complex Politics of Canadian-American Interdependence," International Organization, 28, 4 (Autumn 1974): 596. Joseph S. Nye, Jr., "Transnational Relations and Interstate Conflicts," p. 962.

${ }^{28}$ Morse, Foreign Policy and Interdependence, pp. 4, 315-6. Although I have not yet read it, John Zysman's French Industry Between the Market and the State (Berkeley, Calif.: University of California Press, forthcoming) challenges Morse's interpretation.

${ }^{29}$ Samuel P. Huntington, "Transnational Organizations in World Politics," World Politics, 25 , 3 (April 1973): 343-5.

${ }^{30}$ The same argument has been developed for the security issue in Stanley Hoffmann, Gulliver's Troubles: Or the Setting of American Foreign Policy (New York: McGraw-Hill, 1968). 
between a society-centered American, and a state-centered French, response to international relations. Not the functional logic of different types of international effects but the constraints of domestic structures explain the policy responses of advanced industrial states.

In summary fashion French and American domestic structures could be viewed as different balances of state and society. France embodies the principle of political concentration, the United States the principle of social pluralism. These differences are readily apparent in the scholarly literature on the theory and organization of the state, the character of society and the linkages between state and society. The Old Regime and the Federalist Papers illustrate the different theories of the French and the American state. ${ }^{31}$ In The Old Regime Tocqueville analyzed the process by which, over a period of centuries, the French Crown had succeeded in wresting wealth, status, and power from the landed nobility. The Napoleonic reforms further contributed to a sense of a public interest embodied by centralized political institutions. The subordination to a powerful state made everybody equal. State control increasingly was thought of as both necessary and desirable. The Federalist Papers, on the other hand, are a celebration of the political weaknesses of state institutions. In America the public interest was served not by a concentration of power in strong state institutions but by a dispersion of power among many weak ones. Individual equality was thought to be secured not through the subordination of citizens to a strong public authority but through the safeguarding of the citizen's private autonomy. State control was regarded as neither necessary nor desirable.

These contrasting theories are still reflected in the organization of the French and the American state. In France the rationalization of authority structures preceded the development of participatory institutions. In the United States that pattern of development was reversed. The structure of French governmental institutions is highly centralized and their functions are differentiated. In the United States that structure is decentralized and functions are fused. ${ }^{32}$ The French conception of authority as absolute and the concentration of power in the state contrasts with the American view of authority as circumscribed and the concentration of power ameliorated by a system of checks and balances. General de Gaulle represented the French state as a President-in-tails, pursuing the art of statecraft in magisterial aloofness from everyday politics. Richard Neustadt's description of Truman typifies him as a President-in-shorts ready for continual bargaining and

\footnotetext{
${ }^{31}$ Alexis de Tocqueville, The Old Regime and the French Revolution (New York: Doubleday, Anchor Books edition, 1955). The Federalist (Cambridge, Mass.: Harvard University Press, 1961).

${ }^{32}$ Samuel P. Huntington, Political Order in Changing Societies (New Haven: Yale University Press, 1968), p. 110. The second chapter of Huntington's book is brilliantly wrong in confusing the British and the Continental pattern of political development. Huntington's argument is correct, I would argue, for a comparison of France and the United States.
} 
persuasion and always in search of a deal. ${ }^{33}$ France has been faulted for the "overinstitutionalization" of its political institutions, America for its "underinstitutionalization." 34

The character of French and American society can be contrasted in a similar manner. Stanley Hoffmann has characterized French society, and especially the Third Republic, as a "stalemate society." More recently Michael Crozier has generalized from this particularistic, historically concrete description in viewing France as an archetype of the "stalled society." 35 What has struck observers of American society, on the other hand, has been not stability and stagnation but dynamism and change. French society is homogeneous and its government is monocephalic; American society is heterogeneous and its government is multicephalic. In the face of an omnipotent state the history of social protest in France is a history of revolutions. In the face of an impotant state, the history of social protest in America is a history of riots.

The most important linkages between state and society in France and the United States are public and private bureaucracies. In contrast to other advanced industrial states including Britain, West Germany and Italy, the French and American party systems are less fully developed. Structure and functioning of French and American public bureaucracies reflect the theory and organization of the French and American state. Although changes are notable over time and although deviations can be detected at different levels of organization, French public bureaucracies portray an image of being set apart and above partisan politics. ${ }^{36}$ The American federal bureaucracy, on the other hand, is part and parcel of partisan conflict. Due to this difference in their role perceptions, French civil servants are susceptible only to groups representing the 'public interest' (volonté générale) while in America everybody's interest is thought of as potentially public (volunté des tous). ${ }^{37}$ According to Crozier French public bureaucracy embodies the principle of concentration which leads to the fragmentation of public authority from within; American public bureaucracy embodies the principle of delegation which leads to the colonization of public authority from without. ${ }^{38}$ With the growing intervention

\footnotetext{
${ }^{33}$ Richard E. Neustadt, Presidential Power: The Politics of Leadership (New York: John Wiley, 1964).

${ }^{34}$ Mark Kesselman, "Overinstitutionalization and Political Constraint: The Case of France," Comparative Politics 3, 1 (October 1970): 21-44. Huntington, Political Order, pp. 93-139. Theodor J. Lowi, The End of Liberalism: Ideology, Policy and the Crisis of Public Authority (New York: W.W. Norton, 1969).

${ }^{35}$ Stanley Hoffmann, et. al. In Search of France: The Economy, Society and Political System in the Twentieth Century (New York: Harper \& Row, Harper Torchbooks, 1965), p. 3. Michel Crozier, The Stalled Society (New York: Viking Press, 1973).

${ }^{36}$ Ezra N. Suleiman, Politics, Power and Bureaucracy in France: The Administrative Elite (Princeton, N.J.: Princeton University Press, 1973), pp. 137-80.

${ }^{37}$ Suleiman, Bureaucracy in France, pp. 20-1, 349-50. Grant McConnell, Private Power and American Democracy, pp. 89-90. (New York: Random House, Vintage Books, 1966).

${ }^{38}$ Michel Crozier, The Bureaucratic Phenomenon (Chicago: University of Chicago Press, Phoenix Book edition, 1967), pp. 213-27. McConnell, Private Power, pp. 157-368.
} 
of public bureaucracies in French society control has increased without representation; in the United States representation has increased without control.

An analysis of private bureaucracies as a second linkage between state and society reveals similarly striking contrasts between France and the United States. The anemia of French and the vitality of American voluntary associations have been well documented ever since Tocqueville wrote his Democracy in America. ${ }^{39}$ The Le Chapelier Law of 1791 banned all private associations only a couple of years after The Federalist No. 10 had been written with the express purpose of controlling factions which were deemed to be endemic in American society. This difference in the relative strength of what might be called 'private governments' has persisted over the next two centuries. It is reflected in the great disproportion between the scanty scholarly writings on French and the voluminous literature on American pressure groups. In France public authority has expropriated private initiative. In the United States private initiative has expropriated public authority. As a result French private bureaucracies have been dwarfed by the mobilization of the state while in America the mobilization of social "bias" has diminished state power. ${ }^{40}$

Cursory inspection of the scholarly literature on state and society in France and America points to systematic differences in domestic structures. In France the state is centralized and strong because a feudal society had to be modernized. In America the state is decentralized and weak because society already was modern. ${ }^{41}$ The French state is united and controls an atomistic society. The American state is divided and is controlled by a pluralist society. French political monism and its stalemate society contrast with the American stalemate government and social pluralism. The main linkage between state and society is the public bureaucracy in France and private bureaucracy in America. "Anarchy" in policy making is the result of the centralization of power in France and of the delegation of power in America. ${ }^{42}$ Both countries thus show relatively isolated, decentralized policy networks. But in France these networks are dominated by public bureaucracies and in America by private bureaucracies. French domestic structures are shaped by the scope of public government, American structures by the scale of private government. This pattern of inverted similarity leads to the adoption of different policies.

These differences are very much apparent in the role the two governments play in regulating domestic economic activity. Typical of the French situation is the

\footnotetext{
${ }^{39}$ Arnold M. Rose, "Voluntary Associations in France," in Arnold M. Rose, Theory and Methods in the Social Sciences (Minneapolis: The University of Minnesota Press, 1954), pp. $72-115$.

${ }^{40}$ E. E. Schattschneider, The Semisovereign People: A Realist's View of Democracy in America (New York: Holt, Rinehart and Winston, 1960), p. 30.

${ }^{41}$ Louis Hartz, The Liberal Tradition in America (New York: Harcourt, Brace and World, 1955), pp. 3-32. Huntington, Political Order, p. 135.

${ }^{42}$ Crozier, The Stalled Society, pp. 78-9. McConnell, Private Power, p. 245.
} 
view of a French Director in the Ministry of Industry. "First, we make out a report or draw up a text, then we pass it around discreetly within the administration. Once everyone concerned within the administration is agreed on the final version, then we pass this version around outside the administration. Of course, by then it's a fait accompli and pressure cannot have any effect." 43 This is a far cry from the open system of administration in the United States which encourages the infusion of private interests into public policy. The government's involvement in the economy is marked by state planning in France and social parasitism in the United States. In both countries, it is true, business is big, but in France it is either state-owned (through nationalization) or state-controlled (through the credit market) while in the United States ownership is private and the state, except for the military-industrial complex, is engaged in feeble regulation. In France economic policy is based on the principle of dirigisme of business by government, in the United States on the principle of delegation. ${ }^{44}$ Vertical policy networks which link state and society exist in both countries. But in these networks the tutelle of different Ministries is central in France while in the United States the cooptation mechanisms of civil society matter most. ${ }^{45}$ In France with its non-competitive, differentiated jurisdictional spheres, the state bureaucracy seeks to establish the direction of policy through decree. In the United States with its competitive, overlapping jurisdictional spheres, the state bureaucracy seeks to establish consensus through representation. Since the vertical policy networks are state-centered in France and society-centered in the United States, the approach to economic policy making is consciously planned in France and case-by-case in the United States. ${ }^{46}$

State-centered policy networks in France and society-centered policy networks in the United States define the two end points of a dimension along which advanced industrial states could be ordered. But in all these states, including France and the United States, there are systematic changes under way which blur the ideal-type distinctions I have made here. The French state is far from omnipotent. Bureaucratic rivalries between different ministries can be fierce and problems of policy coordination within the bureaucracy frequently remain unsolved. During the last two decades, furthermore, French society has undergone vast changes as a result of which the art of associability has increased greatly. ${ }^{47}$ Even though their role still remains secondary, interest groups occupy an increasingly important position in the policy process. ${ }^{48}$ The French state has penetrated society, but it is equally

\footnotetext{
${ }^{43}$ Quoted in Suleiman, Bureaucracy in France, p. 336.

${ }^{44}$ Raymond Vernon, Sovereignty at Bay: The Multinational Spread of U.S. Enterprises (New York: Basic Books, 1971), pp. 205-8, 219-23.

${ }^{15}$ Philip Selznick, TVA and the Grass Roots: A Study in the Sociology of Formal Organization (Berkeley: University of California Press, 1949).

46 Andrew Shonfield, Modern Capitalist Planning: The Changing Balance of Public and Private Power (London: Oxford University Press, 1965), pp. 138, 322, 335.

${ }^{47}$ Hoffmann, In Search of France, pp. 70-1. Crozier, Stalled Society, pp. 100-3.

${ }^{48}$ Suleiman, Bureaucracy in France, chapter 12. Michalet, "France," pp. 106-7.
} 
important to note that society has accepted the state. French government is part of the social fabric. As early as the mid-1950s Henry Ehrman noted that in France the boundary between state and society frequently vanishes, and Crozier has more recently spoken of a "profound symbiosis" of state and society. ${ }^{49}$ In the United States the new osmosis between public and private has also been noted. Ideologies and value systems, Ellis Hawley argues, led American politicians "to prefer quasicorporative arrangements and public-private partnership over other alternatives... even when politics or expediency did not dictate it."50 In their complementary analyses of American politics Grant McConnell and Theodore Lowi have fastened on decentralized regulation as the modal policy. ${ }^{51}$ Regulatory policies have led to a mutual openness of the public and the private spheres and a complex pattern of mutual adjustments. These considerations modify the distinction here drawn; they do not invalidate it. The domestic structures of France and the United States are very different.

There is an additional reason why this discussion of France and the United States is illustrative rather than demonstrative. Although I have found it plausible to focus on the interaction of private and public bureaucracies, this is but one among a number of possible modes of analyzing domestic politics. Others may prefer analyses cast, for example, in terms of class or mass behavior, political culture, or political coalitions between economic sectors and the government. Differences between these types of analysis are important but they matter, perhaps, somewhat less in a paper which primarily tries to establish the importance of domestic politics for the study of foreign economic policy.

\section{French and American foreign economic policies}

The first two parts of this paper have laid out two approaches to the analysis of foreign economic policy. The international explanation postulates a functional logic inherent in three distinct international effects. Within particular areas such as energy policy, that logic should make for roughly similar policy responses of advanced industrial states. The domestic explanation, on the other hand, predicts that the structural constraints of domestic policy networks shape policy responses. The similarity in the policy networks linking state and society will determine the degree of similarity in government responses to problems of the international economy. The joint impact of international effects and domestic structures thus condition government policy.

\footnotetext{
${ }^{49}$ Henry W. Ehrmann, Organized Business in France, p. 480 . Crozier, Stalled Society, p. 86.

so Ellis W. Hawley, "Techno-Corporatist Formulas in the Liberal State, 1920-1960: A Neglected Aspect of America's Search for a New Order," unpublished paper, 1974, p. 31.

${ }^{51}$ Lowi, The End of Liberalism. McConnell, Private Power.
} 
But to different men government policy is many things. Which are the critical aspects of foreign economic policy? Since they are of great political importance and figure prominently in recent writings, this paper singles out two aspects of policy in particular: Consistency and content. The consistency of government policy could be defined in terms of the predictability of government responses over time. According to the international explanation the consistency of foreign economic policies of different governments should be about the same. The interpenetration of societies emphasized by the nationalist paradigm should lead to less consistent policies than the interdependence of states highlighted by the realist paradigm for a number of reasons. There are systematic differences in the size, number, and political centrality of political actors (numerous, small, less centrally located actors in society vs. fewer, large, more centrally situated actors in the state), in the relations among political actors (approaching individualized log-rolling in society vs. peak association conflicts in the state), in the degree of ideological conflict (which is lower in society than in the state), and in the locus of government decision making (Parliament vs. the Executive). ${ }^{52}$ If one follows this argument, the interconnection of societies and states depicted by the neo-liberal paradigm should result in policies which in terms of their consistency should fall between these two extremes.

In contrast, the domestic explanation highlights not the similarities in French and American foreign economic policies but rather their differences. Each country follows a logic of its own. State-centered policy networks in France make policies which are "rational" in the sense of comprehensive review, conscious planning and in the emphasis they accord to public power. Society-centered networks in the United States make policies which are "rational" in the sense of mutual adjustment, muddling through and in the role they assign to private power. ${ }^{53}$ If one includes the latent features and secondary effects of policy making, the permissiveness toward capitalist privateers is a central element of coherence in American policy. For reasons of space alone, though, this analysis emphasizes the manifest features and primary effects of foreign economic policies. The policies generated by society-centered networks in the United States will therefore be called "inconsistent," even though in the American madness there is a method which makes these policies predictable in their very "inconsistency." In contrast, the presence of an effective, central decision-making body in France should generate a consistent, that is predictable, foreign economic policy.

This paper analyzes also the content of foreign economic policy. Although the political and economic objectives of a particular policy are always closely intertwined, it is still useful for purpose of analysis to distinguish between the two.

${ }^{52}$ These categories are adapted from Theodore J. Lowi, "American Business, Public Policy, Case-Studies and Political Theory," World Politics, 16, 4 (July 1964): 677-715. The argument has been updated, revised and extended in Lowi, "Four Systems of Policy, Politics and Choice," Public Administration Review 32 (July-August 1972): 298-310.

${ }^{53}$ Charles E. Lindblom, "The Science of Muddling Through," Public Administration Review 19, 2 (Spring 1959): 79-88. 
Some goods, such as profits, typically sought after by societal actors, are divisble and are a matter of absolute gain. Other goods, such as power, normally are the aim of state actors and are indivisible and a matter of relative gain. The international explanation postulates, therefore, that the interpenetration of societies should lead to a primarily economic response while the interdependence of states should result in a primarily political one. According to the neo-liberal paradigm, the growing interconnection of societies and states should lead to a thorough mixture of economic and political objectives.

The domestic explanation, on the other hand, does not emphasize the similarities between French and American policies in different policy areas but focuses instead on how different structures lead to different policies. State-centered policy networks in France facilitate the pursuit of political objectives; societycentered networks in the United States give free play to the quest for economic aims. But, in reality, the boundary which separates the public from the private sphere is permeable in France because indivisible public goods lead also to individual economic gains and that boundary vanishes in the United States because divisible private goods also facilitate collective, political advancement. Recently, two different traditions of writing have pointed out that the apolitical content of American policy can be interpreted as a political choice. In their articles on American domestic politics Bachrach and Baratz have stressed the "two faces of power" and the importance of "non-decisions." 54 Some recent interpretations of American foreign economic policy concur in stressing the political benefits which in recent decades have accrued to the United States-as they did to Britain in the nineteenth century-because its hegemonical position made it possible to take a laissez faire approach in matters of the international economy. ${ }^{55}$ This is in sharp contrast to France and the strong effect which the state's bureaucracy has in the achievement of the political objectives of the French government at home and abroad.

Before testing the international and domestic explanations against secondary data on French and American foreign economic policy, the thorny problem remains of how to link the three international effects to specific policy areas. Since the validity of an indicator is always sanctioned by a combination of the conventions of scientific discourse and the norms of plausibility, there is never a clear one-to-one relation between concept and indicator. The existing literature on international relations suggests to me that the vulnerability of states studied by the realist paradigm is indicated, for example, by energy policy, that the sensitivity of economies analyzed by the neo-liberal paradigm is indicated by international financial policy and that the volume of transactions described by the nationalist paradigm is indicated by commercial policy. The paper now turns to a comparative analysis of French and American policy in these three areas.

${ }^{54}$ Peter Bachrach and Morton S. Baratz, "Two Faces of Power," American Political Science Review, 66, 4 (December 1962): 947-52. Bachrach and Baratz, "Decisions and Nondecisions: An Analytical Framework," American Political Science Review, 68, 3 (September 1963): $632-42$.

${ }_{55}^{5}$ Gilpin, American Hegemony and the Multinationals. Charles P. Kindleberger, The World in Depression 1929-1939 (Berkeley: University of California Press, 1973). 


\section{Commercial policy}

Both the French and the American governments have at their disposal roughly similar arsenals of policy instruments with which they attempt to influence the growing commercial interpenetration of advanced indusîrial states, but compared to the American government, the French government makes a more consistent effort to deploy these instruments in the pursuit of its political objectives. Because of France's relative economic backwardness throughout most of the twentieth century, the French government has traditionally attempted to protect French industry and agriculture against foreign imports. This protectionist stance has declined during the last two decades as the French government, at times belatedly and grudgingly, has come to view the increasing competitive pressures of the international economy as an aid in its restructuring of the French economy. At the same time, though, the French government continues a traditional policy of active support of French exports.

Compared to her European neighbors France had a high tariff structure in the 1950s supplemented by an extensive system of import licensing, quotas, countervailing duties and non-tariff barriers. ${ }^{56}$ But the interest of the French government in a modern, competitive French economy increased in the 1950 s, especially with the advent of the Fifth Republic. "While the underlying causes of change included the inexorable progress of technology and the increasing rigors of international competition, the French government's commitment to embrace the competitive discipline of the modern industrial world was a key factor. This commitment, it should be noted, was sparked not so much by business or the civil service as by the political leadership, and this at the very highest level."57 The commitment to a competitive French economy was a central driving force behind the first French plan, the "Monnet Plan" of 1945-1950, and its importance has not diminished since then. The basic concept of the Fifth Plan, for example, is "to establish a competitive economy as an essential base for political independence, economic growth and social progress." ${ }^{58}$ French commercial policy, in other words, was consciously employed to strengthen the economic base on which a Gaullist foreign policy could be carried out. France did not surrender to the rising tide of commerce among advanced industrial states. Instead her political leaders sought to channel that tide in a direction supportive of the government's political objectives.

This can be illustrated by the partial restructuring of France's chemical industry, an issue on which the government expressed growing but by no means

${ }^{56}$ Henry W. Ehrmann, Organized Business in France (Princeton, N.J.: Princeton University Press, 1957), pp. 392-401. John H. McArthur and Bruce R. Scott, Industrial Planning in France (Boston: Division of Research, Graduate School of Business Administration, Harvard University, 1969), p. 242, footnote 36. Department of Commerce, "Foreign Industrial Nontariff Barriers," United States International Economic Policy in an Interdependent World: Report to the President Submitted by the Commission on International Trade and Investment Policy Papers, (Vol. 1), p. 688. This report will be quoted as the Williams Commission Report.

${ }_{57}$ McArthur and Scott, Industrial Planning in France, pp. 262-3. See also pp. 220, 305-6.

${ }^{58}$ Ibid., p. 129. See also pp. 124-5, 273-6, 449, 462-5. 
clearly formulated political concerns in the mid-1960s. The size and structure of the French chemical industry appeared adequate only in a purely French context. In international comparison the muted character of competition in particular raised some serious questions about the future viability of the industry in international markets. Key problems of the chemical industry were considered in a secret committee of senior civil servants appointed by the Prime Minister in 1964, and it was probable that the government would eventually advise the industry to regroup itself into fewer, internationally more competitive production units. Even though the immediate and medium-range policy was not clear; both in the public and in the private sectors preemptive mergers of companies occurred in a defensive spirit even before the government had decided on a final course of action. The mere expression of an intended change in government policy produced a result in the desired direction. ${ }^{59}$

The dominance of government objectives in the conduct of French commercial policy is illustrated by another episode. After the devaluation of the franc in 1958 and a general improvement in economic conditions, the major problem in the early 1960 s was a comparatively high rate of inflation. As part of its anti-inflation policy, the French government decided to lower tariffs unilaterally on a limited range of commodities. ${ }^{60}$ To the American import lobby, well entrenched in Congressional committees, this would have been a well-nigh inconceivable policy. With the important exception of agriculture, today French imports are, generally speaking, unrestricted. But it is clear that in its adjustment to the growing volume of international commerce the French government has consciously attempted to use its import policy as a tool in the achievement of political objectives.

Since it was always concerned with the French balance of payments, the French government has traditionally taken a strong interest in export promotion. The history of the Common Market since 1958 is largely the history of determined French political efforts to further French agricultural interests in the Common Agricultural Policy. But the government also seeks to influence French industry. Domestic price controls of the French aluminium industry, for example, were so strict in the 1950s that export sales became more profitable than domestic sales even prior to the devaluation of 1957-1958. "In the process the industry prospered and grew to be a more important exporter than ever before."61 Equally instructive of the government's concern over the export performance of the French economy is the case of the Citroën car manufacturer. Citroën's management was slow to respond to the increased opportunities for exports in the late 1950s. Since it had failed to live up to the terms of the government-industry export agreement of 1957 (which specified that each firm was to export two-thirds of increases in production

\footnotetext{
s9 Ibid., pp. 378-82.

${ }^{60}$ Cooper, Economics of Interdependence, p. 237.

${ }^{61}$ John Sheahan, Promotion and Control of Industry in Postwar France (Cambridge, Mass.: Harvard University Press, 1963), p. 59.
} 
during the next twelve months), Citroën was penalized in 1958 by selective restraints on its prices. These restraints produced the desired result. Between 1958 and 1960 the company's exports more than doubled. ${ }^{62}$

The government facilitates French exports through a series of fiscal measures tantamount to subsidies. Most important of all is an export tax rebate of France's value-added tax. Since among all advanced industrial states France ranks second with 15.1 percent in terms of total consumption taxes as percent of GNP (the United States ranks last with 5.2 percent), this rebate is an important aid to French exports. $^{63}$ In addition there are special provisions concerning tax treatment of depreciation allowances and in some cases additional subsidies are paid. Until 1967 the exporter retained control over a specified fraction of the foreign exchange he earned, a measure also designed to stimulate exports. There exists an extensive system of export credits, and the government insures French exporters against commercial and political risks. Finally there are provisions for a government rebate on some of France's high social security payments as a further aid which the government offers to its exporters. ${ }^{64}$ In short, there are a host of different government measures designed to strengthen French exports in the world market. The importance of commercial policy for the French government has recently again been demonstrated. Faced with mounting oil prices the French government has moved, earlier than any other European government, in the direction of meeting the additional costs through what Le Monde calls a "diplomacy of payments." The key to the French strategy is a large export drive which by the end of $1974 \mathrm{had}$ netted the French government commitments of over $\$ 13$ billion of new export orders from the oil countries. ${ }^{65}$ Although this is not enough to pay for all of France's additional energy needs, this policy represents a consciously planned, consistent French response of coming to terms with the recent redistribution of power in international politics.

But the growing interpenetration of advanced industrial societies has also reduced government control over the international forces impinging on the French economy. Forecasts of the relative size of exports and imports in the formulation of the French plan, for example, have become more and more an exercise in wishful thinking. ${ }^{66}$ As a result by the late 1960 s the elaborate system of indicative planning which the government had developed over the preceding two decades had to be discarded. Some observers have overinterpreted this diminution of government control because they viewed the abolishment of indicative planning solely in

${ }^{62}$ Ibid., p. 114.

${ }^{63}$ Williams Commission Report, p. 104.

${ }^{64}$ Paul Arnaud-Ameller, La France a L'Épreuve de la Concurrence Internationale 1951-1966 (Paris: Armand-Collin, 1970), pp. 112-14. Ehrmann, Organized Business, p. 398.

${ }^{65}$ Quoted in New York Times, December 27, 1974, p. 47. See also Dennis C. Pirages, "Strategic Implications of the Energy Crisis," Paper Presented to the Annual Meeting of the International Studies Association, Washington, D.C., February 1975, pp. 33-4.

${ }^{66}$ McArthur and Scott, Industrial Planning in France, pp. 425-7. John and Anne-Marie Hackett, Economic Planning in France (London: George Allen, 1963), p. 30. 
the context of the protectionist commercial policy of the IV Republic and an initially defensive strategy of adjustment to the international market in the late 1950 s. $^{67}$ Such an interpretation deemphasizes unduly the element of political initiative and leadership shown by government policy. The evidence just reviewed suggests to me that the rising volume of commerce did not disempower the French government. It provided, instead, an opportunity for adjustments to which the French government responded in a consistent fashion and in furtherance of its political objectives.

The inconsistency of US commercial policy reflects the bifurcation of American institutions, while the economic content of government objectives expresses the position of strength which economic actors enjoy in their relations with American public authorities. Since 1945 American commercial policy has been made in two distinct policy networks. The first network centers around the Congressional committee structure and is intimately integrated with relatively backward industries interested in increased protection. The second network has formed around the Executive which is loosely linked to modern industries in favor of a free trade policy on world markets. Since they operate at cross-purposes, these two networks have implemented a commercial policy which is inconsistent in comparison with French policy. In both areas of import and export policy the content of policy has been primarily economic; with the decline of America's hegemonic position in world politics these economic objectives stand out even more clearly.

There is some evidence which suggests that the strength of the forces in and around Congress have produced a degree of protection of the American market which is not only greater than might be expected of the leading power of the Western Alliance committed to freeing the flow of international commerce, but which is also greater than in most other advanced industrial states including France. While the average degree of protection afforded by the tariffs remaining after the conclusion of the Kennedy Round is roughly the same in Europe and the United States, these average figures conceal considerable variation in effective protection. Of all the advanced industrial states the Unites States has the highest proportion of tariff rates above 20 percent ad valorem which indicates effective protection for a small group of its industries. ${ }^{68}$ Although precise comparisons cannot be made, the American list of discriminatory practices appears to be as long, if not longer, than what is practised by the traditionally protectionist French government. ${ }^{69}$ American policy relies more heavily on quantitative restrictions of the import of industrial goods than does the European Economic Community, including France. US imports subject to quantitative restrictions were valued at a total of roughly five billion dollars in early 1970 while the corresponding figure for the EEC was less

\footnotetext{
${ }^{67}$ Morse, Foreign Policy and Interdependence.

${ }^{68}$ Williams Commission Report, pp. 82-3.

${ }^{69}$ Department of Commerce, "Foreign Industrial Nontariff Barriers," pp. 688, 698-9. John W. Evans, The Kennedy Round in American Trade Policy: The Twilight of the GATT? (Cambridge, Mass.: Harvard University Press, 1971), p. 259.
} 
than 900 million dollars. ${ }^{70}$ These findings are in agreement with the results of Balassa's calculations according to which United States tariffs in the post-Kennedy Round era are more restrictive of imports than those of the EEC. ${ }^{71}$

Implementation of some of the agreements of the Kennedy Round stalled in the American Congress; the highly controversial American Selling Price system of valuation of imported chemical goods, for example, has remained unchanged. And in contravention to its proclaimed policy of free trade, the American Executive has been increasingly forced by Congressional pressure to urge America's commercial partners to adhere to voluntary export restrictions lest Congress should impose import quotas. The Long-Term Cotton Textile Agreement of 1962 was the first program of this sort. By the end of 1972 the number had swelled to over seventy. ${ }^{72}$ Most publicized of all were the agreements on textiles (Japan) and steel (Japan and the EEC). But to all foreign governments which witnessed the persistent pressure of the American government for a liberalized world trade system in the $1950 \mathrm{~s}$ and $1960 \mathrm{~s}$, the increasing importance of policies abetting restrictive practices must have made American policy appear peculiarly inconsistent.

The character of the domestic politics of tariffs has been analyzed in detail in two studies by Schattschneider and Bauer, Pool and Dexter. ${ }^{7}$ In synthesizing and reanalyzing these empirical investigations Theodore Lowi has noted that this system of policy underwent significant change symbolized by the Trade Expansion Act of $1962 .{ }^{74}$ In the 1930 s and 1950s tariff policies were 'distributive' and were "virtually not policies at all but ... highly individualized decisions that only by accumulation can be called a policy." But in the 1950s this class of policy gradually became 'regulatory' and was "usually disaggregable only down to the sector level." Distributive politics is "a politics of every man for himself," regulative politics "tends to be a residue of the interplay of group conflict."75 Because of the disconnectedness of issues in the distributive arena and the instability of political coalitions in the regulative arena, tariff policies before as well as after 1962 have created inconsistent policies wavering between a free-trade orientation and protectionist practices. ${ }^{76}$

In the export field American commercial policy is distinguished by a modified free trade orientation favored both by business and the executive branch of

${ }^{70}$ John C. Renner, "National Restrictions on International Trade," in Williams Commission Report: Papers (Vol. 1), p. 667.

${ }^{71}$ Bela Balassa, Trade Liberalization among Industrial Countries: Objectives and Alternatives (New York: McGraw-Hill Company, 1967), p. 59.

${ }^{72}$ Richard N. Cooper, "Trade Policy is Foreign Policy," Foreign Policy 9 (Winter 19721973): 27.

${ }^{73}$ E. E. Schattschneider, Politics, Pressures and the Tariff: $A$ Study of Free Enterprise in Pressure Politics, as Shown in the 1929-1930 Revision of the Tariff (New York: Prentice-Hall, 1935). Raymond A. Bauer, Ithiel de Sola Pool and Lewis Anthony Dexter, American Business and Public Policy: The Politics of Foreign Trade (New York: Atherton Press, 1963).

${ }^{74}$ Lowi, "American Business," pp. 692-703.

${ }^{75}$ Ibid., pp. 690-1, 692, 695 .

${ }^{76}$ Ibid., p. 697. 
government. Technologically advanced big business has pressured the government to expand foreign markets. American agriculture also views a large export drive on world markets as essential to its interests. The executive branch of government, on the other hand, has come to regard a free flow of trade as one of the most effective ways to prevent the recurrence of the trade wars and political hostilities which preceded World War II. Liberal and Marxist scholars differ in their interpretations of who does whose bidding in this policy network which links the federal government with the business community. Liberals like Vernon or Behrmann stress the distance between the two while Marxists like Magdoff or Baran and Sweezy emphasize their proximity. ${ }^{77}$ But both types of analysis agree on the central fact that all differences in the roots of interests and motivations of actions notwithstanding, a basic compatibility of interest unites government and business.

In comparison to France, the American government's involvement in export promotion is small. With the worsening of the American balance of payments in the late 1950s, the Eisenhower Administration started an export promotion program which under successive administrations remained small, experimental in outlook and haphazard in implementation. ${ }^{78}$ In 1969, for example, government expenditures on export promotion per thousand dollars of manufactured goods exported was 0.76 dollars in France but only 0.46 dollars in the United States. ${ }^{79}$ And unlike the French government the American President never viewed his support of a free trade policy as a possibly useful policy instrument for reshaping those sectors of the American economy affected by the growth of international competition. The Trade Expansion Act of 1962 provided the Kennedy Administration with an Adjustment Assistance Program designed to support workers and companies in sectors of the economy directly and detrimentally affected by increased foreign competition. But by all accounts the program has been a failure. "Objectives have rarely been achieved by the current program of adjustment assistance because the program is too narrow, inadequate emphasis is placed on anticipating the need for adjustment, the criteria for eligibility have proved too restrictive, and time-consuming procedures have caused lengthy delays in delivery of benefits." ${ }^{80}$ The Williams Report notes further that a sustained American export drive led by the US government would have to include at least four components presently missing in government policy: A less strict application of anti-trust legislation in the export field, liberalization in the administration of the Trade with the Enemy Act, a greater encourage-

${ }^{17}$ Vernon, Sovereignty at Bay, p. 209. Jack N. Behrman, U.S. International Business and Governments (New York: McGraw-Hill, 1971), pp. 171-3. Jack N. Behrman, National Interests and the Multinational Enterprise: Tensions among the North Atlantic Countries (Englewood Cliffs, Prentice-Hall, 1970), pp. 38, 71-4, 159-60. Harry Magdoff, The Age of Imperialism: The Economics of U.S. Foreign Policy (New York: Monthly Review Press, 1969). Paul A. Baran and Paul M. Sweezy, Monopoly Capital: An Essay on the American Economic and Social Order (New York: Monthly Review Press, 1966).

78 Behrmann, U.S. International Business, pp. 186-8.

${ }^{79}$ Harald B. Scott, "Export Expansion for the Seventies ... and Beyond," William Commission Report: Papers (Vol. 1), p. 556.

${ }^{80}$ Williams Commission Report, p. 52. 
ment of exports through the use of tax rebates, and more adequate credit from the Export-Import Bank's short-term and medium-term credit facilities. ${ }^{81}$ The lack of involvement of the American government in the export field and the resulting vacillations in commercial policy have been illustrated by the recent episodes of wheat deals with the Soviet Union and the short-lived soya bean export embargo.

But it would be wrong to stress only the inconsistency of American policy and to emphasize only its economic objectives. The protectionist forces in and around Congress have always pushed for strictly economic objectives of particular industries. But in their conflict with the Executive they prevailed only as long as the tariff question was defined strictly in economic terms as aid for individual firms or industrial sectors. ${ }^{82}$ With its ascendancy to a position of leadership in international affairs, the American Executive eventually succeeded in redefining the question politically in viewing the tariff as an instrument of management of the international system. Although it was notable already in the late 1940s and 1950s this shift became institutionalized only with the adoption of the Trade Expansion Act of 1962. The requirements of hegemony for consistency in pursuit of America's political objectives abroad thus counteracted, to some extent, the effect of domestic structures on US commercial policy. But with the relative decline of the United States in the international trade system, the advocates of protection have once again improved their domestic political standing. After two years of debate, the new Trade Bill adopted in the waning days of the ninety-third Congress extends a negotiating mandate to the President which is "both protectionist in approach and restrictive in detail." 83 Congress, for example, retains the right of subsequent approval on the central question of non-tariff barriers. The weakening of America's position abroad thus is likely to strengthen again the effect of domestic structures on foreign economic policy.

A comparison of French and American commercial policy leads to the unambiguous conclusion of strikingly different policy responses. Not the functional logic inherent in the interpenetration of societies but the constraints of domestic structures explain foreign economic policies. In this analysis, though, international effects could not be disregarded altogether. But these effects were relatively weak, and they had dissimilar consequences for French and American commercial policy. In the face of the growing importance of international markets, the political character of French commercial policy was partly diluted and its consistency was impaired. In the American case, on the other hand, the political requirements of international hegemony helped to transform a bundle of individualized, economic decisions into a moderately consistent policy in the proper sense of the term. On the whole, though, foreign economic policy was shaped primarily by state-centered policy networks in France and society-centered networks in America.

\footnotetext{
Ibid., pp. 120-2.

s2 I am following Lowi, "American Business," pp. 683-4, 699.

${ }^{83}$ New York Times, December 22, 1974, Part III, p. 6. A similar argument is made by B.J. Cohen, "U.S. Foreign Economic Policy," Orbis, 15, 1 (Spring 1971): 232-46.
} 


\section{Financial policy}

The political nature of French objectives and the consistency of French policy are notable also in the field of international finance. The French government faced two problems. First, there was the challenge of the multinational corporations and the growing sensitivity of the French economy to direct foreign investments. That sensitivity was also revealed when an ever-mounting, volatile stream of speculative funds in the Euro-dollar market inundated French money markets. In sharp contrast to the United States, the French government's response was highly interventionist. The growing sensitivity in international money markets did not lead to an abdication of government policy but to a reformulation of political objectives under changing conditions. But in contrast to French commercial policy, the financial weakness of the French economy stopped French policy far short of success.

With the improvement of the balance of payments in the late 1950s French foreign economic exchange dealings were freed de jure. De facto, though, exchange controls requiring government authorization persisted in the 1960s. "The complex and pervasive regulations provided an instrument which could be used not only to protect France's monetary position but also to safeguard other national interests affected by foreign investment." ${ }^{4}$ Despite its title, the 1966 'free-exchange law' did not liberalize the inflow of foreign investment. The French government thus retained a policy instrument at all times with which it could influence the flow of international capital.

The government's concern over the growing importance of multinational corporations in critical sectors of the French economy is a well-known fact. Growing fears of the size and competition of American-based corporations led to a tightening of regulations pertaining to direct foreign investment in the years 1963-1965 because the French government saw a national interest at stake. ${ }^{85}$ This was again evident in the government's veto of efforts by FIAT to buy a 40 percent share of the French car manufacturer Citroën in 1968, and the blocking of Westinghouse's bid for control of Jeumont-Schneider in $1969 .{ }^{86}$ The reluctance of

\footnotetext{
${ }^{84}$ Charles Torem and William Laurence Craig, "Control of Foreign Investment in France," Michigan Law Review, 66, 4 (February 1968): 669. On French monetary policy see Henrik Schmiegelow and Michele Schmiegelow, "The New Mercantilism in International Relations: The Case of France's External Monetary Policy," International Organization, 29, 2 (Spring 1975), pp, 367-92.

ss Charles-Albert Michelet, "France," in Raymond Vernon (ed.), Big Business and the State: Changing Relations in Western Europe (Cambridge, Mass.: Harvard University Press, 1974), pp. 122-3. Jack N. Behrman, National Interests and the Multinational Enterprise, pp. 35, 134. McArthur and Scott, Industrial Planning in France, pp. 254-60. Allan W. Johnstone, United States Direct Investment in France: An Investigation of the French Charges (Cambridge, Mass.: MIT Press, 1965). Robert Gilpin, France in the Age of the Scientific State (Princeton, N.J.: Princeton University Press, 1968), pp. 3-76.

${ }^{86}$ Behtman, National Interests, pp. 150, 162. Gilles Y. Bertin, "Foreign Investment in France," in Isaiah A. Litwak and Christopher J. Maule (ed.), Foreign Investment: The Experience of Host Countries (New York: Praeger Publishers, 1970), p. 119.
} 
the French government to accept foreign takeovers of domestic industry extended thus to American and European corporations alike.

The second problem which the French government faced was the flow of hot, international money. The devaluation of the franc in August 1969 and the gradual improvement of the French balance of payments over the next twelve months brought repeated changes in the government's direct intervention in foreign exchange markets. When the postwar international financial system was unilaterally altered by the United States in August 1971, it was therefore not unexpected that the French government, unlike most others, did not permit the floating of the franc in relation to the dollar. Instead the government sought to preserve at least partial political control by instituting a two-tier foreign exchange market. Official market dealings, based on a fixed exchange rate, would accommodate only trade, tradeconnected and official transactions. A second, financial market would accommodate all other authorized transactions at a floating franc rate. Although the French government insisted on a restructured, fixed-parity system based on the gold value of currencies, it reluctantly agreed, at the insistence of its Common Market partners, on an eventual broadening of the band in which parities would be permitted to fluctuate. The two-tier system was kept in existence for approximately two and a half years even though the French government repeatedly chose to intervene directly in foreign exchange markets to stem the influx of foreign capital.

But the political control of the French government was not unlimited and the consistency of French financial policy was increasingly undermined by the insufficient strength of the French economy. Since France suffered a traditional capital scarcity, the French government welcomed foreign capital for economic reasons and, grudgingly at times, relied in part on foreign investors in its program of regional economic decentralization. ${ }^{87}$ Furthermore, even in instances where it was committed to stop foreign take-overs, the French government was at times unsuccessful as was true of the celebrated alignment of Machines Bull with the General Electric Company of the United States in $1964 .^{88}$ A similar failure of French financial policy has also been evident during the last two years. Due to the sharp increase in the price of oil and the expected deterioration of its balance of payments the French government was compelled to temporarily suspend its two-tier monetary system in January 1974 and to abolish it altogether two months later. Since then, the French franc, like the US dollar, has been permitted to float freely in international money markets.

The growing interconnection between advanced industrial states has thus reduced French control over the inflow of foreign capital in the form of both direct

\footnotetext{
${ }^{87}$ Behrman, U.S. International Business, pp. 34, 36. Vernon, The Economic and Political Consequences of Multinational Enterprise, p. 183.

${ }^{88}$ McArthur and Scott, Industrial Planning in France, pp. 359-68. Behrman, National Interests, pp. 45, 135.
} 
investment and speculative funds. Some have viewed this as evidence of an irreversible shift in the strength of the effect of the international economy on French economic policy. ${ }^{89}$ This interpretation is, however, one-sided and does not square with all of the evidence just presented. The nature of the international economy has, in the late 1960s and early 1970s, undoubtedly led to a failure of French policy. But that policy still betrays a consistent preference for government involvement in the management of foreign exchange markets since only such an involvement insures that the government's political objectives are not disregarded in the conduct of financial policy. Should international financial conditions change, it appears likely that French financial policy will revert to its traditional preference for a direct and active involvement of the government in the regulation of international financial affairs.

During the last decade there has occurred a sizable inflow of foreign funds into the American economy (primarily in the form of portfolio investment). In sharp contrast to the French case, that inflow has remained virtually free of all forms of government interference. ${ }^{90}$ But the lack of political control was more notable on the issue which primarily concerned the American government, the outflow of capital. Unlike the French, the American government has never used the variety of policy instruments with which it might have assured more benefits of foreign investment for the home country. ${ }^{91}$ There existed, it is true, considerable ambiguity over the balance of costs and benefits of capital exports for the US balance of payments and the job situation on the American labor market, and throughout the 1960 s that ambiguity may have contributed to the inconsistency of government policy. But the basic reason for US policy must be sought not in the ambiguous nature of the evidence on benefits and burdens but in the domestic structures which shaped the government's double-edged response. The causes of capital outflow have been ascribed to the role of surplus capital, to the "institutional necessity" of foreign investment due to a Schumpeterian corporate atavism, or to the role of the product cycle in worldwide oligopolistic markets. ${ }^{92}$ Cast from different perspectives all these analyses stress what Barnett and Müller have called the "Latin-Americanization of the United States."93 The economic content and the inconsistency of the government's international financial policy can be adequately explained only by taking account of this domestic factor.

\footnotetext{
${ }^{89}$ Morse, Foreign Policy and Interdependence.

${ }^{90}$ Vernon, Economic Consequences, p. 92. Walter Damm, "The Economic Aspects of European Direct Investment in the United States," in Sidney E. Rolfe and Walter Damm (ed.), The Multinational Corporation in the World Economy (New York: Praeger Publishers, 1970), pp. 37-8.

${ }^{91}$ C. Fred Bergsten, “Coming Investment Wars?" Foreign Affairs, 53, 1 (October 1974): 148. Vernon, Economic Consequences, p. 113.

${ }_{92}$ Magdoff, Age of Imperialism. Theodore H. Moran, "Foreign Expansion as an 'Institutional Necessity' for U.S. Corporate Capitalism: The Search for a Radical Model," World Politics, 25, 3 (April 1973): 369-86. Vernon, Sovereignty at Bay, pp. 60-112.

${ }^{93}$ Richard Barnet and Ronald Müller, "Multinational Corporations II," New Yorker, December 9,1974, p. 100 .
} 
American policy has often been explicitly supportive of foreign investment. Robert Gilpin has argued that the United States tolerated discrimination by the EEC in the 1950s in part because of military and political considerations, and in part because it assumed that the net impact of the EEC would be trade-creating. American-based multinational corporations looked at an integrated European market as an attractive investment prospect. "One major condition, in fact, for American support of the Rome Treaty was a European guarantee of 'national treatment' for the European subsidiaries of American multinational corporations, that is, an assurance that an American-owned company would be treated equally with national firms of European countries. The importance of this policy for the European expansion of American corporations cannot be overemphasized." 94 Foreign investment in less developed countries was also supported. The provisions of the Hickenlooper Amendment attached to the Foreign Aid Bill of 1962 required a cutoff of aid in all instances where expropriation of American assets occurred without adequate compensation..$^{95}$

Tax policy is a third illustration of the support which the American government has extended to the foreign expansion of American corporations in the name of tax neutrality. That policy dates from 1918 but legislation adopted by Congress in $1921,1942,1951$, and 1954 has successively broadened the original provisions in the interest of corporate expansion. ${ }^{96}$ Even though the Williams Commission Report supported the existing system of tax legislation of foreign income it pointed out that the "basic simplicity and neutrality of US taxation has become obscured over the years by a growing complex of laws, rules, and regulations." 97 Recent attempts by the Treasury to cut through the maze of legislative and administrative provisions in the interest of correcting the incentive structure for domestic and foreign investment have failed. ${ }^{98}$ Existing policy specifies that corporations operating through subsidiaries can defer payment of domestic taxes until foreign earnings and dividend income are distributed in the United States. ${ }^{99}$ In addition to tax deferral foreign taxes paid on earnings and dividends received abroad can be credited, as is true in many other countries, against the corporation's domestic tax bill. Several other tax concessions are extended to Western Hemisphere trade corporations and to extractive industries. This system of tax credits and tax deferrals creates an incentive for overinvesting abroad. Under existing tax credit policies the corporation can rely on a highly flexible system of transfer pricing, averaging of foreign tax rates, and the dispersion of the tax burden over several

\footnotetext{
${ }^{94}$ Gilpin, American Hegemony, chapter 4-11.

${ }^{95}$ Charles H. Lipson, "Corporate Preferences and Public Policies: Foreign Aid Sanctions and Investment Protection," unpublished paper, pp. 4-5, 25-6.

${ }^{96}$ US Senate, Committee on Finance, The Multinational Corporation and the World Econo$m y$, February 26, 1973, pp. 16-7.

97 Williams Commission Report, p. 178.

98 Bergsten, "Investment Wars," p. 149.

99 I am following the treatment of Gilpin's American Hegemony, chapter 5-15, to 5-21.
} 
years in order to minimize its US tax liability. Tax deferral encourages foreign investments because it provides a strong incentive for reinvestment rather than repatriation of foreign profits. It encourages, that is, the growth of the corporation outside the United States.

Economic policies supportive of foreign investment were, however, counterbalanced by a series of mildly restrictive measures with which the American government sought to improve its deteriorating balarice of payments in the 1960s. The legacy of the Eisenhower Administration was a piecemeal program which tried to fight the growing balance of payments deficit of the years 1958-1960. Throughout his administration President Kennedy remained extremely concerned over the balance of payments problem without succeeding in fashioning a consistent policy. Throughout 1961-1962 the Kennedy Administration favored cosmetic solutions over more drastic reforms and took what Congressman Reuss harshly characterized as a "boy-scoutish approach to things." 100 In the end President Kennedy settled for a major expansion of American exports as the best solution to the balance of payments problem and to this end pushed the Trade Expansion Act through Congress. But with the French veto of the British entry to the Common Market much of the steam of the Kennedy strategy was lost, and it became gradually clear that the balance of payments situation was increasingly affected by capital outflows which might have to be dealt with directly.

The picture of disjointed, incremental changes which marked government policy under the Kennedy Administration is characteristic also of the series of measures with which the Johnson Administration sought to diminish the outflow of American capital. The Interest Equalization Tax on portfolio investment was singularly inappropriate to deal with increases in direct foreign investment. There are speculations that the then Undersecretary of the Treasury, Robert Roosa, "came up with this type of indirect control to forestall a more radical control proposal, and therefore, the State Department and the Council of Economic Advisors were not apprised of the plan until a day or two before the public announcement." 101 As a result taxable capital outflows dropped rapidly to negligible proportions while non-taxable outflows rose to fill the gap. ${ }^{102}$ Due to their ineffectiveness the voluntary capital controls of 1965 were made mandatory in 1968, relaxed in 1969 and rescinded in 1974. These measures may have slightly improved the short-term appearance of the United States balance of payments. ${ }^{103}$ But for three reasons these restraints were much less restrictive than the foreign exchange controls employed by the French government. Liquid funds could be shifted freely by individual investors. Individual financing transactions were not

\footnotetext{
100 Quoted in Arthur Stein, "The Kennedy Administration and the Balance of Payments," Honors Thesis, Cornell University, 1972, p. 43. See the discussion on pp. 35-44.

101 Ibid., p. 58.

102 Cooper, Economics of Interdependence, pp. 137-8.

103 Behrman, U.S. International Business, pp. 204-11.
} 
subject to detailed scrutiny since the government had simply set a ceiling on capital exports within which investors were free to act as they saw fit. Finally, except for liquid assets held by direct investors there was no overall control policy directly affecting payments for foreign goods or services which required an accounting of foreign assets. ${ }^{104}$ This was, then, a comparatively indecisive policy. Although the American business community was not involved in the discussions leading up to this series of policies, the Johnson Administration felt compelled to "sell" the controls to business after their imposition and to involve business as heavily as possible in their administration. ${ }^{105}$ Business opposition to the policy remained minor because these measures were too weak to significantly slow down corporate expansion abroad. ${ }^{106}$

But American financial policy was more complex. The structure of American domestic institutions explains why the basic objectives of American policy were economic and why the growing dollar deficit led to no more than piecemeal attempts at redress. But its self-assigned role as surrogate Central Bank of the Bretton Woods system of international finance forced upon the United States government political considerations dealing with the viability of the entire system and pushed it to adopt, half-heartedly, measures of control which ran against deeply ingrained political values and economic interests. The failure of American policy makers to move from policy initiation to effective policy implementation revealed, however, the structural constraints which the American policy network imposed on American foreign economic policy. Symbolized by its unilateral departure from the Bretton Woods system in August 1971 and the dismantling of the entire foreign investment restraint program in 1974, the erosion of America's hegemonic position in international financial markets will undoubtedly lead to a further accentuation of these structural constraints.

Because of the great difference in their domestic policy networks, French and American financial policies diverged in intention and implementation. Public or semi-public corporations are more easily controlled in France than are private corporations in the United States. Even though French government and business objectives often ran counter to one another on the question of foreign capital inflow, the government had its way most of the time. Serious, overt conflict was missing in the United States because political-military expansion abroad was congruent with the investment strategy of large corporations: American business and governments had a shared interest in an overvalued dollar throughout the 1960s. In the area of taxation in particular American corporations have succeeded in making profits private and costs public; in France that statement could at times be reversed. ${ }^{107}$

104 Samuel Pizer, "Capital Restraint Program," Williams Commission Report: Papers (Vol. 1), p. 100 .

${ }_{105}$ Behrman, U.S. International Business, pp. 148-53, 184-85.

106 Vernon, Sovereignty at Bay, p. 212.

${ }^{107}$ Gilpin, American Hegemony, Chapter 7, p. 24. Behrman, National Interests. p. 135. 
But an exclusive focus on the different domestic constraints imposed on foreign economic policies neglects important pieces of evidence. International effects were noticeable, more noticeable in fact than in the area of commercial policy. Differences in the structure of French and American policy networks notwithstanding, in today's international money markets the franc and the dollar both float. For two reasons, however, this fact is no more than a partial support for the international explanation. First, as was true of commercial policy, the international effect lacked a functional logic of its own and was dissimilar in its impact on French and American policy. Dwarfed in comparison to the increasing size and volatility of international funds, the French reluctantly relinquished government control in 1974 for sheer lack of financial muscle. American policy, by way of contrast, reacted primarily in a political fashion to the effects of international money markets. Ending the system of dollar convertibility in 1971 undoubtedly was forced upon the government by the deterioration of the American balance of payments over the preceding fifteen years. But the political causes and consequences of that move were of greater importance than the economic ones. Due, in part, to the political logic of the international financial system, the United States continues to enjoy today a leading though no longer dominant role among the advanced industrial states. The international explanation is impaired for a second reason. The present similarity of French and American policy may be deceptive. It is highly probable, in my opinion, that altered circumstances in international relations will witness the resurfacing of very different French and American approaches to problems of the international economy in the near future.

\section{Energy policy}

The dissimilarity of French and American policy is evident also in the field of energy and especially oil policy. France depends more on oil imports than does the United States, but the growth in international interdependence and in vulnerability has prompted both governments to cite reasons of national security in following a policy which has had primarily political objectives for the French and primarily economic objectives for the American government. Although on questions of oil the French government has attempted to increase its autonomy for the last five decades, that policy has been fully developed only during the last fifteen years. ${ }^{108}$ In the interest of autonomy the French government has been willing to pay a heavy economic price. "It would be an unjust exaggeration to say that oil prices in France will be simply marked up to whatever is needed to make ERAP (Entreprise de Recherches et d'Activité Pétrolières) look profitable. But certainly the government will stretch a point (and then another) to prevent the appearance of too large

${ }_{108}$ McArthur and Scott, Industrial Planning in France, pp. 342-59. See also Commissariat Générale du Plan, Commission de l'Énergie, Préparation du VIe Plan: Rapport du Comité Pétrole (La Documentation Française, 1971). 
a deficit." 109 A conservative estimate of the government's exploration costs of oil drilling in the French Sahara has been put at 1.2 billion dollars between 1947 and 1962. ${ }^{110}$ Because of large capital requirements and the presence of sizable international competition the pursuit of the government's political objectives has resulted in intimate relations with the industry on terms which are unambiguously of the government's choosing. With numerous policy instruments the government tries to strengthen French influence at the stage of production, refining and distribution.

One of the most important of these policy instruments has been direct government involvement in the operation of French oil companies. The French takeover of German oil assets in the Ottoman Empire led to the founding of the Compagnie Française des Pétroles (CFP) in 1924 under government auspices. The French government owns 35 percent of the company's stocks and controls 40 percent of the voting rights. Due to government support, the CFP became heavily involved in the exploration and production of oil in the Middle East in the 1960s. Its daughter company, the Compagnie Française de Raffinage (CFR) is by government contract entitled to refine 25 percent of the total annual sale of oil products in France. ${ }^{111}$ Since 1945 the French government has set up additional firms which are involved in the exploration, production, refining, and distribution of oil. After the oil discoveries in the French Sahara had been made, the government formed the Union Générale des Pétroles (UGP). In exchange for 40 percent of the shares of the new company, Caltex sold its entire French assets, including a large refinery located in the vicinity of Bordeaux. Thus the government significantly increased the proportion of government-controlled oil to be purchased by private distributors. ${ }^{112}$ Since the French government wanted to further strengthen its hand in the production of Algerian oil and on questions of oil policy more generally, it amalgamated a number of firms involved in production, refining and distribution into the wholly state-owned ERAP in 1965. Together with their affiliates the CFP and ERAP offer the French government a firm base in the industry from which to pursue its primarily political objectives.

That policy has included a whole range of devices designed to strengthen the position of French companies against foreign competition. For the purpose of raising the funds necessary for the costly and risky business of oil explorations, the government has established five savings institutes which it either owns or controls. Private citizens investing in the stocks of these institutes have been offered not only tax incentives but a government-guaranteed minimum dividend. Although these

109 Adelman, World Petroleum Markets, p. 236.

110 J. E. Hartshorn, Politics and World Oil Economics: An Account of the International Oil Industry in its Political Environment (New York: Frederick A. Praeger, 1967), p. 263.

${ }^{11}$ Albert Mulfinger, Auf dem Weg zur gemeinsamen Mineralolpolitik: Die Interventionen der offentlichen Hand auf dem Gebiet der Mineralolindustrie in Hinblick auf den gemeinschaftlichen Mineralölmarkt (Berlin: Duncker \& Humblot, 1972), p. 100.

${ }_{112}$ Johnston, United States Direct Investment, pp. 33-4. Sheahan, Promotion and Control, p. 201. 
financial intermediaries raise private capital, they also insulate the French oil companies from all private influence.

Since the 1920s a system of quotas has limited the role of foreign-owned corporations in the importing, refining, and distribution of oil in the French market. ${ }^{113}$ A revised quota system, introduced in 1963, limits the import of crude oil from outside the franc zone so as to favor the more expensive oil imports from Algeria. At the same time the government-controlled UGP was assigned a surprisingly large allocation of 14.5 percent of the total quota for crude oil imports originating outside the franc zone. Regulations, furthermore, require that 90 percent of all finished oil products have to be taken from domestic refineries over which the government's control has increased. The government's hold over the distribution system has also been tightened; since 1964 no new retail gasoline outlets can be constructed without direct government approval. ${ }^{114}$ Tax legislation reminiscent of the American depletion allowance further strengthens the government's hand in shaping oil policy. But in comparison to the American oil depletion allowance two differences stand out. First, in the interest of French autonomy a 50 percent tax rebate was allowed only for oil explorations in France or the franc zone. With the loss of Algeria the government has extended the geographic area to which this tax credit applies. But even under the new system the government retains final say over which oil explorations and productions do and which do not qualify for preferred tax treatment. Secondly, the tax rebate is allowed only if the funds are reinvested in new oil exploration ventures within the next five years. ${ }^{115}$

At an estimated annual investment cost running in the hundreds of millions of dollars these policies have succeeded in creating a sizable measure of French independence. In 1968 total French oil consumption exceeded total production of French companies by only a small margin. ${ }^{116}$ In fact, though, the government prefers that only about 50-60 percent of French consumption be covered by the production of French companies. But every barrel imported by a non-French company should be balanced by a barrel of French-produced petrol sold somewhere else. The government objective of controlling 50-60 percent of the refining and distribution of oil products has been exceeded in refining ( 80 percent) and has fallen short in distribution ( 35 percent). ${ }^{117}$ The mix of policies adopted led to a steady decline of the relative share of American investment in the French petroleum industry. ${ }^{118}$ On the question of oil supply it is unlikely that the French government would be as open to political blackmail by the American government now as it was at the height of the Suez crisis in 1956.

\footnotetext{
${ }^{13}$ Denis Touret, La Régime Française d'Importation du Pétrole et la Communauté Économique Europeenne (Paris: Pichon et Durand-Auzias, 1968).

${ }_{114}$ Johnston, United States Direct Foreign Investment, p. 34.

115 Mulfinger, Mineralolpolitik, pp. 119-21.

116 Ibid., p. 118.

117 Ibid., p. 97. Johnston, United States Direct Investment, pp. 51-2.

118 Ibid., p. 46.
} 
This is not to argue that the French government is not open to blackmail. Together with all other advanced industrial states France has become increasingly dependent on Arab oil imports. Discovery of oil in the French Sahara appeared as a great boost to the French objective of independence. But after Algeria's independence the prospects of a sizable and secure flow of oil to France gradually dimmed. ${ }^{119}$ An amendment to the 1962 Evian agreement concluded between the French and the Algerian governments assured France of continued, privileged access to Algerian oil as well as the acceptance of oil payments in francs. The Algerian government improved its financial position considerably in a more substantive agreement concluded in July 1965. From then on the relations between the two countries deteriorated. In 1968 the Algerian government nationalized the country's domestic distribution system which involved twelve French companies. In 1970 unilateral Algerian price increases (from 79 cents to 1.21 dollars per barrel) left the French companies and government helpless. Final testimony to the erosion of what de Gaulle had viewed as a "privileged relationship" was the nationalization of 51 percent of the productive capacity of French companies as well as all of the pipelines and natural gas production in 1971. After difficult negotiations, this amounted to about a two-thirds confiscation of what French policy makers "had fondly thought to be "their own' oil." 120 But at a greatly reduced scale and at higher prices, Algerian oil continues to be shipped to France. CFP, furthermore, concluded in June 1973 and in February 1974 new agreements on joint research, exploration and production. The aim of the French government continues to be maximum feasible autonomy from Anglo-Saxon oil corporations and Middle East oil. At a very high economic price, French oil policy has been geared consistently to the achievement of this political objective.

This is in contrast to the American experience. Although American dependence on foreign oil has also grown since the end of World War II, the overwhelming proportion of foreign oil was imported by American corporations. Privatelyowned corporations have been in intimate contact with the American government. Stephen Krasner writes bluntly, "In its simplest terms, American policy can be seen as an effort to provide energy within the constraints imposed by the political power of the oil industry." 121 And Robert Engler summarizes the results of his research by writing that "the petroleum industry has harnessed public law, governmental machinery, and opinion to ends that directly challenge public rule." 122 Under the guise of national security American oil policy has been shaped by nongovernmental

119 Keesing's Contemporary Archives, February 12, 1972, pp. 25083-8.

120 M. A. Adelman, "Is the Oil Shortage Real? Oil Companies as OPEC Tax-Collectors," Foreign Policy, 9 (Winter 1972-1973): 96.

121 Stephen D. Krasner, "The Great Oilsheikdown," Foreign Policy, 13 (Winter 1973-1974): 131.

122 Robert Engler, The Politics of Oil: $A$ Study of Private Power and Democratic Directions (New York: Macmillan, 1961), p. 9. For a somewhat more balanced but concurring conclusion see Vernon, Sovereignty at Bay, p. 214. 
actors. This explains why economic objectives have been central and why policy consistency has been low.

Although important changes could already be detected in earlier years, the decisive shift in business-government relations occurred during World War II. ${ }^{123}$ For the purpose of aiding the government's war effort an industrial advisory system was built into the federal bureaucracy and was united with it in terms of personnel. Dismantled in 1945 at the insistence of an industry fearful of potential government involvement in its peacetime operation, the system was resurrected during the Korean War. As is illustrated by the government's response to the Middle East crises in the 1950 s, the typical pattern of policy making was the delegation of decisionmaking powers to the oil industry. ${ }^{124}$ Described as "business statesmanship," this system of private government explains the vacuity and vacillation of public policy. ${ }^{125}$

This is readily apparent in the largely ineffective application of antitrust legislation to the oil industry. When just prior to the entry of the United States into World War II the federal government sought the advice and assistance of the oil industry, it found itself blackmailed. The industry's cooperation was contingent on the suspension of all pending antitrust litigation. It was in keeping with past and future practices that the government surrendered to this demand. ${ }^{126}$ The industry was itself internally divided between large and small, and, more importantly, between international and domestic oil producers. Transmitted by the industry's advisory system into the bureaucracy, these divisions were also felt inside Congress and the party system and thus contributed to the inconsistency of policy. By and large, though, the industry as a whole managed to extract large political privileges and sizable economic rewards from its intimate involvement in the formulation and execution of public policy. This can easily be illustrated on the issue of import quotas and tax legislation.

On the question of quotas, government policy was remarkably vacillating throughout the 1950s. Even though government concern over the increasing dependence on foreign oil imports had been clearly evident for the better part of the decade, the national security argument and the imposition of mandatory import restrictions carried the day only in 1959. After consultation with the oil industry over the rapidly growing share of oil imports in the late 1940s and early 1950s, the government responded twice with a voluntary import restriction program. Because the economic interests of international and domestic producers were affected differently, both programs failed within a very short period of time. It was only after this double failure of Hoover-type policies that the government resorted to mandatory import restrictions in 1959.

${ }^{123}$ Gerald D. Nash, United States Oil Policy 1890-1964: Business and Government in Twentieth Century America (Pittsburgh: University of Pittsburgh Press, 1968).

124 Engler, The Politics of Oil, p. 308.

125 Ibid., p. 335.

126 Ibid., p. 277. 
The favored treatment of the oil industry is also evident in the area of taxation. The American government, like the French, extends numerous privileges to the oil industry including measures such as the depletion allowance, overseas investment insurance, tanker subsidies and a dry hole drilling allowance. But in contrast to the French case these privileges are not used by the American government to provide the oil industry with an incentive structure favorable for the accomplishment of government objectives. Instead, the various measures amount to little more than outright subsidies and private enrichment from the public purse. As has been noted already this is true of the oil depletion allowance. But it is also notable in a system of taxation of foreign investments which has led to a virtual tax exemption of America's major oil corporations during the 1950s and 1960s. Robert Gilpin is right in writing that the large oil multinationals "have enjoyed the best of all possible worlds." 127 In the Middle East the oil corporations operate through branches and the income derived through these foreign operations is included in their American tax return the year it is earned. This system of organization entitles the corporations to claim the depletion allowance and other tax benefits, but it also has the benefit of facilitating agreement between US firms and foreign producer governments since increases in royalty payments can be written off against US tax liabilities. In Western Europe and Japan, on the other hand, the oil corporations operate through a system of subsidiaries which entitles them to tax credits and tax deferral since their earnings are not distributed in the United States. Supplemented by internal transfer pricing this system has led to the corporations' escape of virtually all tax payments in the United States. ${ }^{128}$ Unlike the French, the American government extends these numerous benefits without shaping corporation strategy on questions of production, refining, or distribution.

In foreign affairs the symbiotic relation between government and the oil industry dates back to the $1920 \mathrm{~s}$. In peacetime the American government has done most of the industry's bidding while in times of diplomatic crisis or war the oil industry has reluctantly supported the government. ${ }^{129}$ Like the French, the American government has favored the growth of domestic ownership and control over foreign oil sources. But in contrast to France, the US government has been content with simply pursuing a policy of "Open Doors" without further influencing the corporations' economic strategies. Illustrative of this approach is how the American government helped the multinationals in securing their grip over Middle East oil and the Western European oil market after World War II. ${ }^{130}$ Between 1948 and 1950 the Economic Corporation Administration (ECA) gave aid-

127 Gilpin, American Hegemony, pp. 5-19, 5-20.

128 Cooper, Economics of Interdependence, pp. 102-3.

129 Michael Tanzer, The Political Economy of International Oil and the Underdeveloped Countries (Boston: Beacon Press, 1969), pp. 50-5, 319-44.

${ }^{130}$ Edward H. Shaffer, The Oil Import Program of the United States: An Evaluation (New York: Praeger, 1968), pp. 13-4. 
receiving countries in Western Europe 384 million dollars worth of oil aid produced by American companies in the Middle East. As a result the relative share of dollar oil in the Middle East rose from 38 percent in 1947 to 45 percent in 1950. In addition ECA mostly refused to finance the construction or renovation of European-owned refineries thus further increasing the hold of US companies over this vital market. Largely as a result of these policies Europe became dependent on American-produced oil in the Middle East within four years. In 1947, a year before the Marshall Plan, Europe received 43 percent of its crude oil from the Middle East. By 1950 that percentage had increased to 85 percent. More gradually the United States replaced Britain as the leading Middle East oil power. In 1947 Britain controlled 44 percent of gross fixed assets while the American share was about 40 percent. By 1959 the US share had risen to 50 percent while the British share had declined to 18 percent. But once the door was open for the oil multinationals the American government, unlike the French, stayed out. The shift of power to the OPEC countries in the early 1970s and especially since October 1973 has again revealed the high degree of independence which American oil corporations enjoy. The at least temporary explosion of oil profits in 1973-1974 showed that, unlike Secretary Kissinger, the oil companies share with the oil producing states a fundamental interest in further price increases. In their role of "tax collectors" 131 of the OPEC countries, the economic interests of the oil corporations contradict the political interests of the American government. In this particular instance at least sovereignty is at bay abroad, in part because it has been abandoned at home.

A comparison of French and American oil policies points to striking differences. Although in both countries considerations of national security led to import restrictions and government support, policies were shaped by state-centered networks in France and society-centered networks in the US. At all phases of policy making public authority responded with policy direction in France and with policy delegation in the United States. The difference between the consistent, political French response and the inconsistent economic American response to increases in international interdependence has recently been reflected again in the steps the two governments have taken in dealing with the oil crisis. Compared to the French energy program of March 1974, the implementation of a large-scale, government-led export drive and the revaluation of the French gold-stock at open market prices in January 1975, the American government has shown no creative policy response some fourteen months after the October War. The assessment of the Church Committee on Multinational Corporations for the period 1971-1973 thus may have a more general validity. "The US government had no energy policy and had no institutional capacity to formulate one. International oil questions were the exclusive purview of the companies and a select group of State Department of-

131 Adelman, "Is the Oil Shortage Real?" p. 78. 
ficials." ${ }^{132}$ The American approach to energy policy since 1973 expresses the dominant position of private interests in energy policy. These interests benefit from oil price increases which enhance monopoly rents without stimulating large-scale expansion of alternative sources of energy, and they do not tolerate a reduction of oil consumption through domestic taxation. The different constraints of French and American domestic structures explain their different policy responses to the growth of international interdependence.

Despite these obvious and important differences in French and American energy policy, it would be mistaken to disregard altogether the importance of international effects. These effects did not have an inherent logic of their own, but affected French and American policy differently. The consistency of French policy was undermined by the economics of international oil while the inconsistency of American policy was somewhat tempered by the political requirements of America's role in the world economy. Both countries, it is true, have become increasingly dependent on the countries producing oil rather than the major multinationals. In this respect French experiences with Algeria from the mid-1960s on were simply a prelude to what the United States has experienced with the major Mideast oil states since 1973. But France's greater dependence on foreign oil imports, like that of the other West European states, makes the French concern for secure supply overriding. The Kissinger approach to the OPEC cartel, on the other hand, was tougher and had political objectives. The failure of that approach can only in part be accounted for by American inability to finance itself the 25 billion dollar credit system which was to aid oil-importing countries in their balance of payments problems. Of greater importance is the apparent impossibility of reform in American energy policy in the domestic political context. In this particular crisis Kissinger has advocated a policy which was "semi-Gaullist" in that it served the political interests of the United States but promised some benefits to America's allies as well. But unlike De Gaulle, Kissinger lacked the domestic support-indications of drastic changes in America's domestic energy policy-essential for the success of his policy. Even if one grants, therefore, that international effects cannot be altogether disregarded, one is still left with the conclusion that domestic politics play an essential role in the formulation of energy policy.

\section{International effects, domestic structures, and foreign economic policies}

How do these studies in foreign economic policy compare with the major predictions of international and domestic explanations? The international explanation predicts change, the domestic explanation its absence in the content and the

${ }^{132}$ New York Times, January 12, 1975, p. 36. 
consistency of government responses to international economic problems. According to the international explanation the French and the American governments could be expected to respond in a similar manner to the functional logic which is inherent in each of the three policy areas investigated in this paper. The domestic explanation, on the other hand, predicts that government policies are shaped not by the character of the issue but by the constraints of domestic structures. Because policy networks are state-centered in France and society-centered in the United States, across these three policy areas French and American responses should differ. With some modifications to be noted below, the evidence just reviewed shows that an analysis of domestic structures is indispensable for an understanding of foreign economic policy.

These domestic structures generate foreign economic policies which express the particular logic inherent in each of the two policy networks. Although the French state is heavily involved in all three areas of policy making, its presence is more noticeable in energy than in commercial policy, with financial policy falling somewhere between these two. Correspondingly, the reflection of private interests is stronger in American energy policy than in commercial policy, with financial policy again occupying an intermediate position. The growing interdependence of states elicits the most direct French and American responses because on matters of energy French public authorities view their power as threatened and American private actors their profits.

But a comparative study of energy policy illustrates that in addition to international effects and domestic structures size and level of technological development should be included in the analysis. French energy policy, like French financial policy, fell short of success for the simple reason that France lacked the absorptive capacity of and relative autonomy from international effects which the United States enjoyed for reasons of sheer size. The need for strong government action was therefore greater in France than in the United States. In addition France's relative technological backwardness favored state intervention of a kind which Gerschenkron has described as typical of all industrial latecomers. ${ }^{133}$ The technological superiority of the American economy, on the other hand, made unnecessary, at least until the mid-1960s, special government efforts. This difference was perhaps most evident in the French and the American approach to commercial policy. Differences in the relative size and technological development of France and the United States thus reinforce the differences of domestic structures on policy content and consistency. But compared to the impact of domestic structures, these two factors play, in my opinion, no more than a secondary role.

In commercial, financial, and energy policy international effects acted as an additional factor on government policies. Unexpectedly, though, these effects were

\footnotetext{
133 Alexander Gerschenkron, Economic Backwardness in Historical Perspective: A Book of Essays (Cambridge, Mass.: Harvard University Press, 1962), pp. 5-30.
} 
dissimilar in their impact on French and American policy. Both governments were challenged most seriously by international developments which revealed the onesidedness of their domestic policy networks. As a power aspiring to a major role in world politics, the consistent pursuit of France's political objectives was diluted and compromised by economic changes abroad such as the growth of the Eurodollar market, and the growing power of the OPEC cartel. In contrast, the requirements of international hegemony forced the United States government to pursue some political objectives in addition to the satisfaction of private economic interests. In addition, those requirements also introduced a modicum of consistency into American foreign economic policy in all three policy areas. French foreign economic policies were affected primarily by the dynamic growth of international markets, American policies by the requirements of international hegemony. ${ }^{134}$ International effects thus create "problems" in policy making because they impinge on the weaker components of domestic structures and, through them, affect policy content and consistency. An analysis of domestic structures is, therefore, indispensable for an understanding of foreign economic policies.

The history of the last two decades supports the conclusion that differences in the constraints of French and American domestic structures have led to the adoption of dissimilar foreign economic policies. In the Kennedy Round, in the negotiations over a reorganization of the international monetary system and, more recently, on questions of energy policy the conflict between the French and American governments has dominated all others. Although this paper has selfconsciously skirted problems of policy coordination between governments, its focus on policy content and policy consistency was not accidental. Consistency and content of policies, I would argue, are the two primary dimensions which affect the coordination of policies between states. This paper has illustrated how in the French-American case government policies diverged along both dimensions, thus raising the greatest problems for the coordination of policies. The corporatist policy networks in the Federal Republic, to take another example, generate a foreign economic policy which is reminiscent of French policy in its great consistency but resembles American policy in its economic content. Policy coordination between West Germany and France as well as West Germany and the United States has, therefore, been more successful than between France and the United States. It should be relatively easy to work out the implications of this paper's conclusion for the prospects of policy coordination between states.

\footnotetext{
134 C. Fred Bergsten, Robert O. Keohane and Joseph S. Nye, "International Economics and International Politics: A Framework for Analysis," International Organization 29, 1 (Winter 1975), 18-20. A comparative study of foreign economic policy is, thus, very much a matter of proper perspective. Lowi and others have been right in arguing that foreign policy issues in American politics are treated more consistently than other issues in domestic politics; yet in comparison to France, United States foreign economic policy undeniably looks inconsistent. Similarly, Morse is partially correct in pointing out how international markets have undermined French foreign policy; but he fails to consider that for other governments, like the American, international processes may have primarily political repercussions.
} 
The central conclusion of this paper is unambiguous. Content and consistency of foreign economic policies result as much from the constraints of domestic structures as from the functional logic inherent in international effects. A correct determination of the relative weight of international and domestic factors is one of the keys to an adequate analysis of international politics. Although domestic and international forces are complementary rather than competing in their impact on foreign economic policies, it appears that on questions of the international economy international politics can no longer be adequately analyzed from the lofty heights of the international system alone. The political causes and consequences of many current international problems of the international economy should instead be interpreted as well from the perspective of domestic politics. 